Building on a pension: Second pillar wealth as a way to finance real estate?

Monika Bütler, Sabrina Stadelmann

September 2019 Discussion Paper no. 2019-13 updated January 2020 


$\begin{array}{ll}\text { Editor: } & \text { Vanessa Pischulti } \\ & \text { University of St.Gallen } \\ & \text { School of Economics and Political Science } \\ & \text { Department of Economics } \\ & \text { Müller-Friedberg-Strasse 6/8 } \\ & \text { CH-9000 St.Gallen } \\ & \text { Phone +4171 224 23 07 } \\ & \text { Email seps@unisg.ch } \\ & \text { School of Economics and Political Science } \\ & \text { Department of Economics } \\ & \text { University of St.Gallen } \\ \text { Publisher: } & \text { Müller-Friedberg-Strasse 6/8 } \\ & \text { CH-9000 St.Gallen } \\ & \text { Phone +41 71 224 23 07 } \\ & \text { http://www.seps.unisg.ch }\end{array}$




\title{
Building on a pension: Second pillar wealth as a way to finance real estate? ${ }^{1}$
}

\author{
Monika Bütler, Sabrina Stadelmann
}

Author's address:

Monika Bütler

Swiss Institute for Empirical Economic Research (SEW)

University of St.Gallen

Varnbüelstrasse 14

$\mathrm{CH}-9000$ St.Gallen

Email monika.buetler@unisg.ch

Author's address:

\author{
Sabrina Stadelmann \\ Swiss Institute for Empirical Economic Research (SEW) \\ University of St.Gallen \\ Varnbüelstrasse 14 \\ $\mathrm{CH}-9000$ St.Gallen \\ Email sabrina.stadelmann@unisg.ch
}

\footnotetext{
${ }^{1}$ We are grateful for the comments received from Christoph Basten, Martin Brown, Winfried Koeniger, Gabriel Okasa, as well as the participants at the meetings/workshops of the Household Finance Seminar (St.Gallen, 2017), European Public Choice Society (Rome, 2018), International Conference on Pensions, Insurance and Savings (Lisbon, 2018), Swiss Society of Economics and Statistics Annual Congress on Household Finance (St.Gallen, 2018), International Workshop on Pensions, Insurance and Savings (Tampere, 2018), Pensions Workshop 2019 "Choice in Pensions in Switzerland and the Netherlands" (St.Gallen, 2019), Swiss Workshop on Local Public Finance and Regional Economics (Lugano, 2019), Economics of Ageing Workshop (Sydney, 2019), and seminar participants at the University of St.Gallen. We further thank the pension provider for the data. This research project was supported by the Swiss National Science Foundation grant 100018_172821.
} 


\begin{abstract}
Home ownership is not only an important asset, but also provides an income stream in kind. If individuals use pension savings to purchase real estate, they face a trade-off between alleviating borrowing constraints when young and lower liquid retirement means when old. We study the decision to withdraw retirement assets for home purchase in advance by analyzing a recent reform. A change in down payment requirements made such early withdrawals less attractive, as borrowers are obliged to provide a larger amount of nonpension equity for a home purchase. Using individual-level data from a large Swiss occupational pension provider, we find that the share of individuals who withdrew in a given year dropped by one sixth. For the withdrawers, the average share of pension assets withdrawn decreased by 5.5 percentage points, mainly driven by individuals with lower levels of pension wealth and of older age. Nonetheless, our analysis also shows that while limiting second pillar withdrawals can aggravate the borrowing constraint to some degree, they are not the only constraining factor when purchasing a home.
\end{abstract}

\title{
Keywords
}

Retirement, annuity, home ownership

\section{JEL Classification}

D81, D91, H24, J26 


\section{Introduction}

We shed some light on the interplay between retirement savings and real estate purchases in the context of a change in regulation in Switzerland. The purchase of real estate can work as a substitute for retirement savings. It may also act as an insurance against fluctuations in rental costs (Sinai and Souleles, 2005). Effectively, when withdrawing pension assets for real estate purchase, individuals face a trade-off between the utility streams of owner-occupied housing and reduced pension assets in the future, along with low portfolio diversification. Due to the special nature of home ownership, the policy maker faces the question whether mandatory retirement savings should be allowed to finance residential property.

Advanced withdrawals of pension assets to purchase owner-occupied housing are possible in countries like Australia, Singapore, or Switzerland. The Central Provident Fund in Singapore allows its insured individuals to make (unlimited) withdrawals for housing since 1968. In Australia, the option to withdraw retirement assets for home ownership was only introduced on July 1, 2018. It allows first home buyers to employ a maximum of AUD 30,000 of voluntary superannuation (paid for with employment-related contributions) to place a deposit on residential property. In Switzerland, withdrawing pension wealth accumulated in the mandatory second pillar for owner-occupied housing has been possible since 1995 (regulated within the Federal Law on Occupational Retirement, Survivors' and Disability Pension Plans). There is no upper limit on withdrawals for individuals below age 50; older individuals can claim the higher amount of either the accumulated wealth at age 50, or half their current accumulated wealth.

Due to the importance of the second pillar in Switzerland, with contribution rates of up to $20 \%$, pension savings account for a large fraction of middle-aged households' wealth on average, thus making withdrawals attractive. Every third purchase of a home between 2013 and 2017 in Switzerland was partially financed by advance withdrawals at an average amount of CHF 72,000 in 2017 (MoneyPark, 2017). Hence, this policy is an important part of home ownership promotion, which was introduced to the constitution in 1972.

Nevertheless, advance withdrawals have come under scrutiny due to macroeconomic conditions. An exceptionally expansive monetary policy with key interest rates close to zero 
made property ownership more attractive and pushed up real estate prices. Regulators feared both an overheated property market and an excessive debt burden on households, especially in case of increasing interest rates and falling house prices. As of July 2012, stricter rules for the financing of residential property apply. Households are obliged to provide at least $10 \%$ of the property's value as so-called hard equity, i.e., equity other than pension assets. Previously, it had been possible to finance the required down payment of $20 \%$ entirely with accumulated pension wealth from the second pillar. The second change, a requirement to reduce the loan-to-value ratio to a maximum of two thirds within 20 years, basically implemented what had already been common practice before the revision.

Interestingly, the new macro prudential restrictions came in the form of a rule for professional conduct imposed by the Swiss Bankers Association and encouraged by the Swiss National Bank. Such minimum requirements merely provide guidelines for the internal bank procedures that deal with the lending business (Swiss Bankers Association, 2014).

While the aggregate number of advance withdrawals in Switzerland has been on a decreasing trend since 2004 due to decreasing home purchase transaction volumes and rising real estate prices (cf. Figure 1), there were still around 30,000 withdrawals annually. Around the time of the reform, the aggregate number of withdrawals dropped from more than 25,000 in 2011 to less than 20,000 in 2013, corresponding to a decrease of more than one fifth. It remained at this low level for the rest of the observation period (2013-2015). Therefore, the stricter equity regulation coincided with a non-negligible aggregate effect on the usage of advance withdrawals.

Drawing on administrative data from a large Swiss employer-based pension provider, we explore how the reform influenced withdrawal decisions at the individual level. The pension provider covers employees all over Switzerland and thus approximately $1.1 \%$ of the Swiss labor force. The insured individuals tied to this pension provider are representative of the Swiss population. We use the universe of individuals insured by this pension provider in the years just before and just after the reform, namely 2011 and 2013, incorporating information on select socio-economic factors, retirement balances, and advance withdrawals. We investigate whether a policy change in terms of guidelines for minimum requirements is effective along two adjustment margins: the extensive and the intensive margin. We further analyze the 
FIG. 1: Aggregate number of Advance Withdrawals Per year in Switzerland

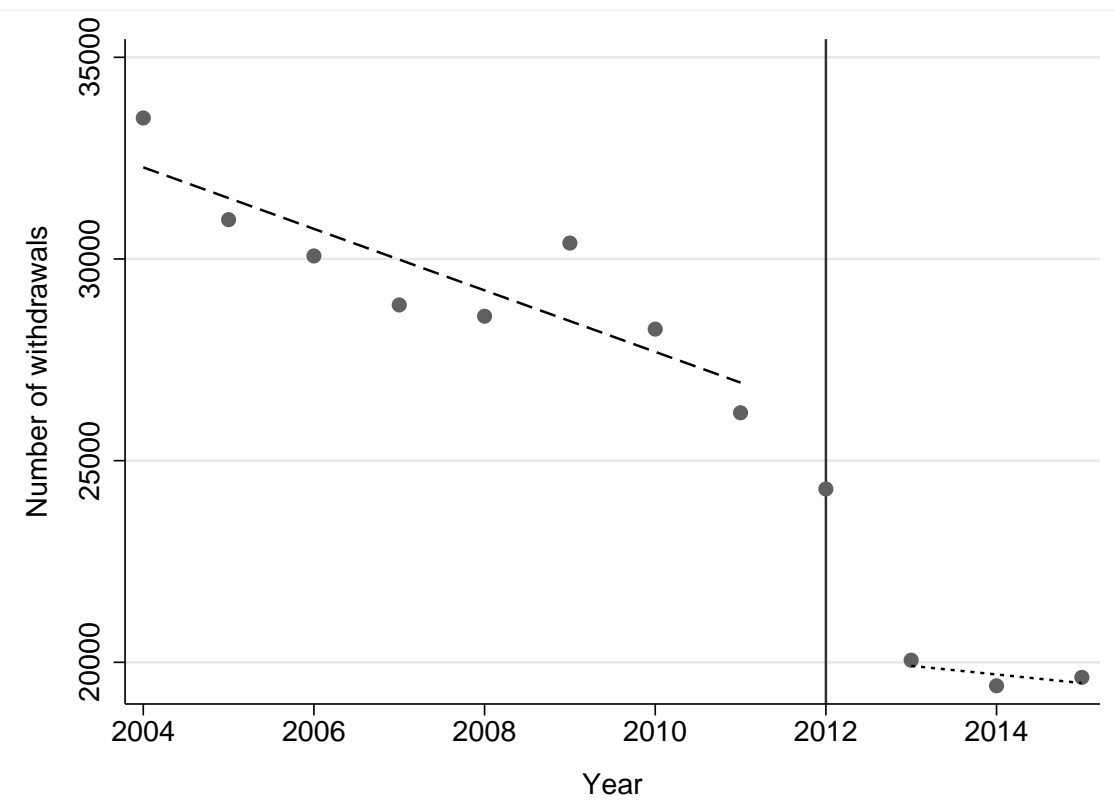

Note: Aggregate number of advance withdrawals per year in Switzerland between 2004 and 2015. The vertical line depicts the reform date. Data stem from the Federal Statistical Office.

characteristics of individuals withdrawing pension assets in advance before and after the reform to uncover the underlying mechanisms at play. Do individuals abstain from a home purchase, postpone their purchase, find other sources of equity or buy a cheaper home in response to the reform?

We observe fewer advance withdrawals after the reform - the individual probability of claiming pension assets drops. The effect of the reform also materializes along the intensive margin: If individuals decide to make a withdrawal, they claim a smaller share of pension assets. As such, changes in access to home ownership have distributional consequences. The share of pension wealth withdrawn after the reform especially dropped for older and lower income individuals. Even after the reform, however, withdrawals play an important role in overcoming liquidity constraints in home purchases. Results suggest that some potential buyers were constrained more by the hard equity requirement after the policy change and less by their pension wealth in financing owner-occupied housing. Our results are neither driven by changes in wages, the unemployment rate, interest rates, nor real estate prices around the reform. In a robustness check examining only foreign residents who should have access to 
mortgage contracts with foreign banks and thus serve as a control group, we find no effect of the reform.

Our paper relates to three strands of literature. First, early withdrawal of pension wealth is an aspect of portfolio choice in retirement savings. Yogo (2016) shows that housing is the most important tangible asset for the average retiree among four major asset classes (bonds, risky assets, annuities and housing). It serves two purposes: a consumption value from living in the home and a wealth store, which can be left as a bequest or invested to pay for healthcare costs. Considering housing equity as a low-risk investment and underlying insurance provision to buffer long-term care costs, Fehr and Hofmann (2019) find that long-term care risks may be an important driver for home ownership.

Second, our analysis touches on the substitutability between real estate and retirement savings. While we analyze the decision to substitute pension savings with housing equity, most existing literature investigates the possibility to unlock housing wealth as a means of retirement income. Clearly, owner-occupied housing equity has a consumption benefit. Whether the elderly consider downsizing their home equity for general consumption depends on the ratio of income to housing equity and the adequacy of saving for retirement (Venti and Wise, 2004). For countries with declining fertility rates and high life expectancy, e.g., Japan, Mitchell and Piggott (2004) suggest the unlocking of housing wealth assets via reverse mortgages to finance retirement expenditures. The liquidation of housing wealth is especially attractive for "income-poor and house-rich" households (Angelini et al., 2014). In terms of adequacy of retirement saving, home ownership depends on whether housing wealth is considered a substitute for financial wealth to support post-retirement consumption. For US households, Venti and Wise (2004) find that housing equity should not be decumulated to finance non-housing consumption if savings are sufficient to maintain the pre-retirement standard of living.

Finally, our analysis also relates to the annuitization decision at retirement, as advance withdrawals for housing are an anticipated cash out of retirement savings. As demonstrated by Yaari (1965)'s seminal paper, annuities provide sizable utility gains for the individual. In an empirical application, Brown (2001) examines the role of life annuities for insuring against the expenses associated with longevity. Davidoff et al. (2005) find that market 
incompleteness and liquidity constraints may limit the optimal degree of annuitization to some extent. Moreover, as Bütler and Ramsden (2016b) show, differential tax treatments of the lump sum and annuities impact an individual's cash out decision at retirement. Seemingly, the trade-off between liquidity of means and longevity insurance, as well as most factors influencing annuitization, can also be expected to have a bearing on the withdrawal decision.

The paper proceeds as follows. In Section 2 we provide an overview of the institutional setting: the Swiss pension system and promotion of home ownership. Section 3 introduces the dataset and describes the empirical strategy. We present the main results in Section 4 , and shed light on the mechanisms at play in Section 5. Section 6 concludes the study.

\section{Institutional setting}

\subsection{The Swiss pension system}

The Swiss pension system is based on three pillars: the Federal Old-Age and Survivors' Insurance (first pillar), the mandatory occupational pension scheme (second pillar) and private pension savings (third pillar) ${ }^{1}$. The pay-as-you-go first pillar pension aims to provide a subsistence income to all retirees. Its benefits are related to the number of contribution years and (weakly) to income. In addition, retirees whose income level is insufficient to cover basic living expenses adequately can claim means-tested supplemental benefits.

The second pillar is an occupational pension scheme with the goal to maintain living standards after retirement. All pension providers are obliged to insure the mandatory share of income which ranges between CHF 21,330 and CHF 85,320 (in 2019). There are strict regulations in terms of the minimum accrual and conversion rates, which translate the pension wealth into an annuity.

The statutory retirement age is 65 for men and 64 for women. Upon retirement, employees have different withdrawal options. They may claim the accumulated retirement capital as a lifelong monthly annuity, a lump sum, or a combination of the two. Annuity payments are

1 Art. 111 and 112 of the Swiss Federal Constitution (Bundesverfassung der Schweizerischen Eidgenossenschaft; BV) provide the legal basis of the Swiss pension system and Art. 113 BV explicitly governs the second pillar. 
proportional to the accumulated retirement wealth and determined by the conversion rate.

Second pillar wealth is a very important part of individual wealth in Switzerland. In 2017 retirement assets from occupational pension schemes and private pension savings accounted for $40 \%$ of total household financial assets - whereby the vast majority of these retirement assets $(82 \%)$ are attributed to the second pillar (Swiss National Bank, 2018b). Interestingly, - and of significance for the interpretation of our results - the correlation between pension wealth and non-pension wealth is very small. ? $^{2}$ To some degree pension wealth serves as a substitute rather than a complement to non-pension wealth. Foellmi and Martínez (2017) give three possible reasons for the low correlation between the two: (1) Tax incentives make it more profitable for wealthier individuals to withdraw their pension wealth as a lump sum (also includes the advance withdrawal of pension assets); (2) pension contributions are capped for high-income earners and low-pension wealth individuals may save outside the public pension system to compensate; (3) richer individuals may accumulate less pension wealth by deciding to work less.

The third pillar is an optional, fully privately financed pension, divided into a regulated (3a) tax-favored scheme and an unregulated (3b) scheme without preferential tax treatment. Generally, withdrawals from pillar 3a are permitted five years prior to the ordinary retirement age (Art. 3 BVV 3). Early withdrawals are only possible for a limited number of uses, among them the financing of home ownership or the repayment of a mortgage. The option to use third pillar capital for real estate purchase was not affected by the reform.

\subsection{Promotion of home ownership}

Switzerland's home ownership rate of $41.3 \%$ ranks low compared to an average rate of 69.3\% in the European Union 28 in 2017 (Eurostat, 2019). The main reasons include relatively high house prices due to land scarcity in high density urban areas, but also a relatively attractive rental market in terms of costs and supply (Wüest Partner, 2014). While somewhat regulated, the rental market for apartments is liquid and works well. Even among high income

${ }^{2}$ Figure 9 in Appendix Billustrates the correlation between pension assets and total non-pension financial assets (bank accounts, bonds, stocks, mutual funds, contractual savings and life insurance) using data from the Survey of Health, Ageing and Retirement in Europe (SHARE). 
households, renting is very common. Moreover, in contrast to many other countries, house owners hardly benefit from preferential tax treatment or easier access to social assistance.

In 1972, the Swiss constitution was amended to include a legal basis for the promotion of home ownership. The implementation of measures to facilitate owner-occupied housing was generally left to the cantons as is typical for federalist Switzerland. Examples of such policies are favorable imputed rental value for tax purposes, as well as full deductibility of the interest rate and most renovation costs. An important nationwide policy to promote home ownership is the possibility to withdraw second pillar wealth for the purchase of a home. This option was introduced in 1995 with an amendment of the Federal Law on Occupational Retirement, Survivors' and Disability Pension Plans. . $^{3}$ Advance withdrawals should facilitate the acquisition of residential property even for households with low non-pension wealth. Note that the policy never targeted low-income households (who are only marginally covered by the second pillar). Rather, it is aimed at alleviating the liquidity constraints of a wide range of potential beneficiaries, particularly those of younger households, whose savings outside the large second pillar are insufficient to satisfy down payment requirements. As a side effect not specified in the policy goals - , advance cash outs allow for some limited tax savings, as each withdrawal from pension wealth is taxed separately.

Individuals can withdraw pension assets from their second pillar (occupational pension wealth) and third pillar (restricted voluntary insurance) funds to finance the purchase of residential property for personal use $\mathrm{H}^{4}$ About half of the withdrawn pension assets used to finance the purchase of owner-occupied housing come from the second pillar alone, a quarter from both the second and third pillar, and another quarter from the third pillar alone (Seiler Zimmermann, 2015). Thereby, residential property may take the form of both ownership or co-ownership (i.e., condominium ownership).

Pension assets for the purchase of home equity may be claimed either in the form of an advance withdrawal of pension assets (equity) or in the form of a pledge (liability). A pledge

3 Art. 108 BV builds the legal basis for the home ownership promotion in Switzerland, Art. 30 of the Federal Law on Occupational Retirement, Survivors' and Disability Pension Plans (Bundesgesetz über die berufliche Alters-, Hinterlassenen- und Invalidenvorsorge; BVG) and Art. 1-7 of the Ordinance on the Encouragement of the Use of Vested Pension Accruals for Home Ownership (Verordnung über die Wohneigentumsförderung mit Mitteln der beruflichen Vorsorge; WEFV) build the legal bases for advance withdrawals.

4 Alternative reasons for an advance withdrawal of pension assets are for investment into a home, the amortization of a mortgage and the acquisition of shares of housing cooperatives or similar investments. 
allows for better borrowing conditions with lower interest rates and amortization, since banks use the pledge as collateral. Without this additional security, most banks allow for a loan of $80 \%$ of the property's value at most. Pledges do not reduce pension wealth as long as mortgage loans are paid. We focus first on the advance withdrawal of pension assets, as this is the most relevant case empirically. In a second analysis in Section 5, we consider the effect of the reform on the option to pledge pension wealth as an alternative source of funding.

Advance pension withdrawals count as equity, enabling home ownership with lower private capital requirements. This is a decisive argument in light of banks' mortgage lending rule, by which at least $20 \%$ of the property's value must be equity (NZZ, 2014). However, the minimum equity share of $20 \%$ is not always adhered to and may be managed at the discretion of the parties in the contractual mortgage agreements. A specific loan-to-value ratio cannot be enforced legally. Other than pension withdrawals, equity may include inheritance advances, non-interest-bearing and non-refundable loans, the lending of account balances, securities, and the repurchase value of insurance policies (Swiss Bankers Association, 2014, p. 4).

Apart from the down payment requirement, there is also an income requirement. Banks assess the adequacy of a purchaser's income to cover mortgage payments and other housing costs even at higher interest rates. A widely used rule of thumb is that interest payments at an imputed rate of $5 \%$ together with costs for upkeep (estimated at $1 \%$ of the house value) should not exceed one third of a buyer's gross income (Credit Suisse, 2017). Given Switzerland's high real estate prices, this is an important hurdle for potential house buyers.

In 2013 the average ask price for a condominium (single-family home) was CHF 643,500 (CHF 1,150,000) (Wüest Partner, 2014). A Swiss household's average annual disposable income of CHF 85,560 in 2013 (Federal Statistical Office, 2019b) implies a condominium (single-family home) price to income ratio of 7.5 (13.4). The $20 \%$ down payment requirement for a condominium (single-family home) would imply CHF 128,600 (CHF 230,000), the income rule for a condominium (single-family home) CHF 96,525 (CHF 172,500)

5 5\% of the CHF 514,800 (CHF 920,000) external capital, in addition to costs for upkeep of $1 \%$ of the condominium's (single-family home's) value of CHF 643,500 (CHF 1,150,000), multiplied by a factor of 3. 


\subsection{The reform: Tightening of down payment restrictions}

Prior to July 2012 it was possible to fully comply with the "20\% equity requirement" with pension assets (Swiss Bankers Association, 2014, p. 3). Accordingly, Swiss Financial Market Supervisory Authority (Eidgenössische Finanzmarktaufsicht; FINMA) and the Swiss National Bank (SNB) feared that the use of pension assets as down payment might further feed a real estate bubble. At almost $150 \%$ in 2017, the rate of mortgage debt relative to GDP in Switzerland is one of the highest worldwide (Credit Suisse, 2018). Consequently, authorities called for stricter regulation to limit banks in excessive risk-taking in terms of mortgage lending (FINMA, 2016).

On July 1, 2012, a drastic change was introduced to the financing guidelines for residential property. The new rules require households to provide at least $10 \%$ of the property's value as hard equity, i.e., equity other than occupational pension assets from an advance withdrawal of second pillar wealth (see FINMA, 2012). Additionally, new borrowers must reduce their loan-to-value ratio to a maximum of two thirds within 20 years ${ }^{6}$

The new explicit norms governing the amortization period went largely unnoticed in the discussion following the policy change. This is not surprising as the new rules hardly deviate from what was common practice prior to July 1, 2012. While the specific amortization rules were left at the discretion of the parties in the contractual mortgage agreements, it was customary that $1 \%$ of the mortgage be paid back every year. Moreover, most banks required the mortgage holder to reduce the mortgage to two thirds until age 65 at the latest.

The new guidelines apply to new home purchases and mortgage increases (Swiss Bankers Association, 2014 p. 3). They were originally passed by the Board of Directors of the Swiss Bankers Association on May 14, 2012 and approved by the FINMA on May 30, 2012. They entered into force on July 1, 2012. The policy introduced is a rule of professional conduct introduced by self-regulation by the Swiss Bankers Association. These minimum requirements provide guidelines for the internal bank procedures dealing with the lending business (Swiss Bankers Association, 2014). As such, they have no direct legal bearing or any direct impact on the underlying contractual relationship between banks and their customers.

${ }_{6}^{6}$ On September 1, 2014 the amortization period was shortened further from 20 years to 15 and since then loans must be repaid linearly, i.e., with regular installments (FINMA, 2014). 
However, FINMA, the regulatory authority, has approved the requirements of the Swiss Bankers Association, making these an integral part of banking regulation (FINMA, 2008; Federal Act on the Swiss Financial Market Supervisory Authority (FINMASA), Art. 7 (1, lit. b, 3)). In addition, the Federal Council has revised the Capital Adequacy Ordinance (cf. Art. 72(5) of the Swiss Capital Adequacy Ordinance; Eigenmittelverordnung (ERV)) (FINMA, 2012). Banks violating the requirements of the Swiss Bankers Association will have to back the respective mortgage credits (granted after July 1, 2012) with additional capital, which might be costly for them.

The revised Capital Adequacy Ordinance also contains a further instrument for reducing mortgage risks. If a bank grants a mortgage amounting to more than $80 \%$ of the collateral value, it will be required to back it with a higher level of capital. This measure came into force on January 1, 2013. As a further measure, from July 1, 2012, the Federal Council has at its disposal a new capital buffer for all banks that can be selectively and temporarily activated for specific sectors, such as the mortgage business. For the individual, these additional instruments had no direct effect, but they helped to discipline the banks and thus increase compliance with the new rules.

\subsection{Advance withdrawals of pension wealth for home ownership}

Advance withdrawals from pension savings can stem from both the second and the third pillar. In contrast to second pillar wealth, withdrawals from pillar 3a have always been considered "hard equity" and are thus not affected by the reform. Regardless of the specifics of the reform, it has consistently been optimal to withdraw wealth from the third pillar before withdrawing pension assets from the second pillar for a number of reasons. First, withdrawals from the third pillar are easier as they are only lightly regulated. Second, third pillar capital is less attractive as a base for retirement income than second pillar wealth as it neither benefits from legal minimal accrual rates, nor does it offer beneficial annuity conversion options. On average, however, withdrawals from the third pillar are only half the size of the second pillar withdrawals for home ownership (Seiler Zimmermann, 2015).

Moreover, the advance withdrawal of pension assets in the second pillar is subject to 
certain restrictions. The minimum amount for an advance withdrawal is CHF 20,000 and may be claimed every five years. For insured individuals older than 50 years, an advance withdrawal is restricted to the greater value of the following two figures: (i) the vested termination benefits stated at the age of 50 (increased by the repayments made after the age of 50 and reduced by the amount used for home ownership on the basis of advance withdrawals or pledged deposits); (ii) half of the difference between the vested termination benefits at the time of the withdrawal and the vested termination benefits already used for home ownership at that time. For example, a 60 year-old with retirement assets of CHF 200,000 at the age of 50, and CHF 450,000 at the age of 60, may withdraw up to CHF 225,000 in advance (ii). In contrast, someone with CHF 350,000 at the age of 60 could withdraw CHF 200,000 (i). Furthermore, the advance withdrawal reduces claimable pension assets in the future. For instance, if the conversion rate of a pension fund is $5.5 \%$, an advance withdrawal of CHF 100,000 decreases annual payments by CHF 5,500.

Advance withdrawals are possible up to three years before retirement. Upon request, individuals receive an application form for an advance withdrawal of pension wealth for home ownership from the administration of the pension provider. Married individuals or those in a registered partnership must provide the written consent of their spouse/partner. The applicant must provide supporting documents that the home is intended for personal use. Importantly, the applicant never sees the advance withdrawal, which rules out a different use. The pension provider transfers the advance withdrawal from the individual's pension account directly to either the seller or developer of the real estate or the loan provider. Upon pay-out, the advance withdrawal is subject to a one-off capital tax, similar to the lump sum tax at retirement. The tax burden depends on the size of the advance withdrawal and the canton of domicile. Simultaneously, the pension provider reports to the land registry with a note declaring a sale restriction for the acquired property. 


\section{Data and empirical strategy}

\subsection{Data}

Our study is based on individual-level administrative data from a large Swiss employer-based pension provider. A network of roughly 50 private-sector companies is associated with this pension provider. The pension fund covers employees all over Switzerland, corresponding to approximately $1.1 \%$ of the Swiss labor force. It is organized as an autonomous fund without re-insurance, holding around $\mathrm{CHF} 20$ billion worth of pension assets (which is far above the CHF 320 million of an average sized pension fund).

We draw from four datasets. For the main analysis, we consider the universe of individuals insured by this pension provider in the years just before and just after the reform, namely 2011 and 2013. We have information on socio-economic factors (gender, age, marital status, annual income), retirement balances (pension assets), and advance withdrawals (date, amount, domicile). Besides, we restrict our sample to individuals who are eligible to withdraw pension assets (i.e., those with a minimum of CHF 20,000 in pension assets, and who have not withdrawn pension assets in advance for home ownership in the five years prior to 2011), and to Swiss residents. Although an advance withdrawal may be used to finance home ownership abroad (i.e., for cross-border commuters), the guidelines of the stricter equity regulation apply to Swiss banks only. To show how our population of interest differs from the excluded individuals, we report a comparison of means of pre-reform individual and regional characteristics in Table 1. By definition, the excluded sample does not withdraw pension assets in advance. The selected sample also has a higher probability to pledge on average. Likewise, due to the minimum pension wealth restriction, the selected sample is older and has higher annual incomes and more pension wealth on average. In terms of regional characteristics, the selected sample is more likely to reside in locations with higher real estate prices and tax rates.

We link this data to administrative data on tax rates (cantonal and municipal tax multipliers), the degree of urbanity, and average real estate prices. Tax and urbanity data originate from the Federal Statistical Office. Data on real estate prices were obtained from the company Wüest Partner. They cover small-scale transaction price indices at a regional 
Table 1: SAmple SELECTION: COMPARISOn OF MEANS PRE-REFORM

\begin{tabular}{lccccc}
\hline \hline & Excluded & Selected & Diff. & SE & p-value \\
\hline Withdrawal (binary, \%) & 0.00 & 0.77 & 0.766 & 0.097 & 0.000 \\
Pledge (binary, \%) & 0.06 & 0.20 & 0.143 & 0.052 & 0.006 \\
\hline Age & 34.72 & 45.61 & 10.887 & 0.116 & 0.000 \\
Female (\%) & 65.11 & 53.00 & -12.112 & 0.619 & 0.000 \\
Married (\%) & 54.88 & 64.47 & 9.590 & 0.605 & 0.000 \\
Income in CHF 1,000 & 48.92 & 67.28 & 18.362 & 0.382 & 0.000 \\
Pension assets in CHF 1,000 & 18.74 & 157.59 & 138.842 & 2.049 & 0.000 \\
\hline Condominium price index & 154.59 & 156.83 & 2.238 & 0.431 & 0.000 \\
Single-family home price index & 141.90 & 144.19 & 2.296 & 0.360 & 0.000 \\
Income tax rate (\%) & 10.13 & 11.26 & 1.126 & 0.069 & 0.000 \\
Capital tax rate (\%) & 3.57 & 4.51 & 0.936 & 0.020 & 0.000 \\
Urban & 2.29 & 2.29 & -0.005 & 0.014 & 0.686 \\
& & & & & \\
Observations & 8,114 & 29,758 & & & \\
\hline \hline
\end{tabular}

Note: Comparison of means of individual and regional characteristics between the excluded and selected sample pre-reform (in 2011). Selected are individuals who are eligible to withdraw pension assets (i.e., those with a minimum of CHF 20,000 in pension assets, and who have not withdrawn pension assets in advance for home ownership in the five years prior to 2011) and Swiss residents. Excluded are non-eligible residents residing in Switzerland. Based on individual-level data from a pension provider in 2011. The sample is unbalanced, and sample sizes are 8,114 for the excluded and 29,758 for the selected observation samples.

leve $\sqrt{7}$ by year. The indices are separate for single-family homes and condominiums. They reflect prices of a medium-sized property with average amenities.

A comparison of means for the observation years 2011 and 2013 is presented in Table 2. We observe that $0.77 \%$ and $0.57 \%$ of insured persons within our pension provider withdraw pension assets in advance of around CHF 73,000 on average (corresponding to roughly two thirds of their total pension wealth) in the years 2011 and 2013, respectively. This is in line with the established fact that every third purchase of home ownership between 2013 and 2017 in Switzerland was partially financed by advance withdrawals with an average amount of CHF 72,000 per withdrawal in 2017 (MoneyPark, 2017): Given a home ownership rate of $41.3 \%$ in Switzerland in 2017 (Eurostat, 2019), that roughly one third of the home owners use pension assets to finance the home purchase and that we observe these individuals over two years (corresponding to roughly $1 / 20$ of their work-life), we would expect a withdrawal

\footnotetext{
7 Switzerland is subdivided into 106 so-called MS regions (mobilité spatiale; spatial mobility), which are used in particular for scientific and regional policy purposes. They typically comprise several municipalities and are characterized by a certain spatial homogeneity.
} 
rate of around $0.69 \%$.

Considering that in 2013 the $20 \%$ down payment requirement for a condominium (singlefamily home) would imply CHF 128,600 (CHF 230,000) on average (cf. Section 2.2) and that the average withdrawal of insured persons in the same year amounted to CHF 72,190 (cf. Table 2), it seems that, on average, individuals withdraw less than the $20 \%$ down payment. While this is an average number, it seems unlikely that precautionary motives on top of financing requirements for home purchase play an important role in withdrawing pension wealth in advance. Moreover, typical risks for precautionary motives, i.e., health issues and loss of employment, are very well covered by the Swiss social security system (OECD, 2019).

Our second dataset covers all advance withdrawals by individuals tied to this pension provider between 1995 and 2017, if the individual was still tied to the pension provider as of 2011. Therefore, if an individual claimed her pension money for real estate purchase in 2004 but dropped out of the fund before 2011 (e.g., due to a change of employer or retirement), she would not be included in our dataset. The data are thus complete in 2011 but become successively less so the further we go back in time. As a consequence, the number of withdrawals before 2011 is a lower bound. However, this does not pose a problem in our empirical analysis, as we only compare the observation year 2011 with 2013, in which we observe not only advance withdrawers, but all individuals. We use the dataset of advance withdrawals to analyze pre-treatment trends.

The remaining two datasets are used for an analysis of the underlying mechanisms. Our third dataset covers all sales transactions for real estate in the canton of Zurich between 2007 and 2015. For each transaction we employ information on the year of change in ownership, the property (type, municipality, net price, net price per square meter), and the buyer (age, nationality, gender). If more than one person is buying the property, the information on the older person is recorded. As our fourth dataset, we draw from the Swiss Household Panel, which is an annual panel study based on a random representative sample of private households in Switzerland. We observe changing living conditions between 2004 and 2015, in particular for those households moving residence.

Table 9 in Appendix $B$ provides a brief description of the variables used and gives information on the data sources. 


\subsection{Empirical strategy}

We study the impact of the policy change to restrict the use of pension wealth for owneroccupied property along two adjustment margins. First, the extensive margin: Do individuals still make advance withdrawals to finance owner-occupied housing? Second, the intensive margin: Conditional on their withdrawal, how much do they withdraw on average and relative to their total pension wealth? Moreover, we investigate the characteristics of individuals withdrawing pension assets before and after the reform. Finally, we are interested in the underlying mechanisms at play. How do the individuals respond to the reform: Do they abstain from a home purchase, postpone their purchase, find other sources of equity, or buy a cheaper home?

For identification purposes, we exploit the temporal discontinuity in mortgage regulation created by the reform of July 1, 2012. The requirement of $10 \%$ hard equity, i.e., equity other than advance withdrawals, implies that prospective home owners require equity other than that of their pension wealth of at least $10 \%$ of their home's value 8

We define the reform as the treatment of individual $i, T_{i}$. It is determined by the time of withdrawal of individual $i, t_{i}$, relative to the Reform date of July 1, 2012:

$$
T_{i}= \begin{cases}1 & \text { if } t_{i} \geq \text { Reform } \\ 0 & \text { if } t_{i}<\text { Reform }\end{cases}
$$

We test the following regression equation:

$$
y_{i}=\alpha+\beta T_{i}+\gamma X_{i}+\chi Z_{i}+\epsilon_{i}
$$

$y_{i}$ is the outcome variable, i.e., either the probability to withdraw pension assets for real estate purchase, or the advance withdrawal as a share of the total pension wealth. Our coefficient of interest is $\beta . X_{i}$ is a set of individual-level controls: pre-reform age (5-year dummies), an indicator for being female, an indicator for being married, annual income, and pension assets. $Z_{i}$ are controls at the individual's level of residence: real estate prices, tax

\footnotetext{
8 The introduction of the amortization guidelines did not change the implementation de facto.
} 
rates, and the level of urbanity. $\alpha$ is the intercept and $\epsilon_{i}$ denotes the error term.

Our analysis is based on panel data combining pre- (2011) and post-reform (2013) observations. The sample is unbalanced and encompasses 29,758 observations for 2011 and 30,562 for 2013. The unbalanced sample sizes stem from fluctuations in the number of employees tied to the pension provider. We observe $84.6 \%$ of the individuals in both periods. In Table 2 we provide a balance test to check whether attrition is random. Due to the high population overlap, most individual characteristics are very similar before and after the reform. While differences in age, share of married individuals, annual income and pension wealth are statistically significant, they are small in magnitude. Regardless of the reform, individuals withdraw CHF 73,000 on average, which amounts to about two thirds of their pension wealth. However, the share of withdrawers and pledgers dropped significantly between 2011 and 2013 by 20 percentage points and 7 percentage points, respectively.

Moreover, the share of withdrawers constrained by their pension wealth does not change significantly on account of the reform. With the variable Constraint: CHF 10,000 we measure the share of individuals who withdraw their possible relative maximum $9^{9}$ In Section 5 we analyze the effect of the reform on the share of individuals who withdraw their relative maximum of pension assets to provide insight into the binding factor: $10 \%$ hard equity or pension assets.

The conditional independence assumption requires that all confounding variables are observed. The choice of covariates in our case is restricted by data availability. However, we control for some of the most important drivers of home ownership that could affect our results (Angelini et al., 2014, Chambers et al., 2009; Chiuri \& Japelli, 2010; Fisher \& Gervais, 2011, Gyourko \& Linneman, 1997; Painter \& Lee, 2009. Turner \& Smith, 2009). Table 2 confirms that the populations observed in 2011 and 2013 are very similar already before conditioning on observables as a balancing measure. Thus, we do not expect a significant change in the estimated effect of the reform on the extensive margin once controlling for individual and regional characteristics. However, changes in access to home ownership have distributional

\footnotetext{
9 The respective relative maximum depends on the age of the insured person. For individuals up to the age of 50 , this amounts to their total pension wealth. For individuals above 50 years of age, the larger value of either their pension wealth at the age of 50 or half of their pension wealth at withdrawal is applicable. From this figure, we subtract CHF 10,000 to define the relative maximum.
} 
consequences. We expect covariates to play a more important role on the intensive margin to balance our samples of withdrawers pre- and post-reform.

We control for both annual income and pension assets. Home-ownership rates are positively related to income (Andrews \& Sánchez, 2011; Angelini et al., 2014, Fisher \& Gervais, 2011; Gyourko \& Linneman, 1997; Turner \& Smith, 2009). Apart from total available wealth being an important determinant of home ownership, pension wealth is also a good proxy for past income. For a given level of income, smaller pension wealth hints at a positively sloped income profile and potentially more alternative equity.

We add age as a possible confounder, as life-cycle models of saving under borrowing constraints predict an increase in the home ownership rate with age as people save and become home owners, followed by a decrease in old age as people draw on their housing equity (Artle and Varaiya, 1978). This hump-shaped home ownership age profile has previously been observed in other data (Angelini et al., 2014; Chambers et al., 2009; Chiuri \& Japelli, 2010; Fernández-Villaverde \& Krueger, 2007; Yang, 2009).

We include gender and marital status as covariates, as women are less likely to purchase real estate (Angelini et al. 2014) and marriage is a positive determinant of home ownership (Angelini et al., 2014; Bourassa, 2015; Chiuri \& Jappelli, 2010)

In terms of regional covariates, we control for both single-family home prices and condominium prices. There is a potential reverse causality with real estate prices: A rise in real estate prices makes it more difficult for individuals to purchase a home. Given this restriction, individuals are less likely to withdraw pension assets in advance for home ownership. Similarly, if advance withdrawals are frequent within a region, real estate prices may be higher.

Moreover, we control for both the capital and income tax rate at the municipal level because combined they change the relative costs of the advance withdrawal. Bütler and Ramsden (2016b) show that large differences in relative taxation can explain a significant part of the variation in annuity rates. Exploiting kinks in the Swiss tax schedule, they find evidence for individual tax optimization strategies. Schmidheiny (2017) provides a summary of robust evidence for households' behavioral responses to local differences caused by the redistribution of fiscal authority to the cantonal and municipal levels.

The capital tax rate has a direct impact on advance withdrawals, as it is applied to the 
total amount of pension assets withdrawn in advance as a one-off lump sum capital tax ${ }^{10}$ Tax schemes for the lump sum create kinks in the marginal tax rate as a function of wealth and differ substantially between the cantons 11

Far less important for advance withdrawals is the income tax rate because the taxable imputed "rental value" and the deductible interest typically offset each other - especially in case of a high loan-to-value ratio. The income tax rises as home owners must tax the imputed rent as income. As a rule of thumb the imputed rental value lies within $60 \%$ to $70 \%$ of the market rent. On the other hand, maintenance costs and mortgage interest can be deducted from taxable income. Thus, if the advance withdrawal from pension assets raises the equity share of the property's value, i.e., reduces the loan-to-value ratio, the mortgage interest payment is reduced, but the income tax burden increased due to a smaller mortgage rate deduction.

\subsection{Identifying assumptions}

The main identifying assumption is that there should be no discontinuities in variables affecting the decision to make advance withdrawals at the time of the reform. In Section 4.3. we show that four important drivers of real estate purchases - interest rates, wages, the unemployment rate and real estate prices — did not change discontinuously around the reform.

A potential threat to identification is other reforms related to home ownership or pensionfund-specific amendments. There were two related national referenda in 2012 which were both rejected in popular votes. The first, rejected by $55.8 \%$ of voters on March 11, 2012, asked for the option to grant sizable tax relief for first time home owners, to be implemented by the cantons.

Three months later, a similar proposal was rejected by $68.9 \%$ of voters in a popular

\footnotetext{
${ }^{10}$ The capital tax rate is based on the withdrawal amount and thus conditional on withdrawing money from the pension assets for real estate purchase. For the non-withdrawers, it is calculated based on an assumed withdrawal of the mean share of $67 \%$ of pension wealth in advance.

${ }^{11}$ An advance withdrawal of pension assets can also give rise to tax benefits to some degree. Depending on the split of pension wealth payouts, an insured individual may bypass a tax progression to a higher marginal rate. Note, however, that given the overall low tax rates of capital withdrawals, these tax optimization considerations do not seem to be of primary importance.
} 
vote ${ }^{12}$ Had the initiatives been accepted, the ensuing tax deductions would have facilitated the purchase of owner-occupied housing. While there were strong indications that the proposals would not pass the vote (the rejection rates of popular initiatives are very high), a certain level of uncertainty remained. Hence, individuals might have postponed their housing purchase until after the outcome of the initiative. If anything, this would only have led to an under-estimation of the true effect of the reform.

Further, anticipation effects could potentially impact our estimated effects: If individuals believed that withdrawing pension assets will become more difficult in the future, they might rush withdrawing funds before the reform is implemented. Such an anticipation effect would have exaggerated the drop in withdrawals by increasing pre-reform withdrawals and depressing after-reform cash outs. To avoid measuring anticipation effects, we focus on observations before the reform was announced (2011) and after it was implemented (2013). The reform was only passed by the Board of Directors of the Swiss Bankers Association and approved by the FINMA in May 2012. The concrete reform specifications were announced in June 2012 a mere month preceding the reform. It was only then that the Federal Council informed the Swiss citizens of the minimum equity rules to be implemented as of July 1, 2012. We find no time pattern in the number or size of withdrawals in 2012.

Monthly media coverage on the promotion of home ownership was quite volatile between 2011 and 2013, and is largely driven by the two rejected referenda mentioned above (cf. Figure 8 in Appendix B] ${ }^{13}$ The reform-specific media coverage after the reform date was mostly related to the implementation of the reform.

The tentative analysis of media coverage suggests no reporting on the stricter equity regulation for owner-occupied home purchases that could have led to anticipation effects. Likewise, anticipation effects seem unlikely because real estate purchases take time (in contrast to the acquisition of more liquid assets).

Finally, there should also be no regulatory changes related to the pension provider that would incentivize the insured to adjust their withdrawal behavior besides the reform. Although there was a change in the pension provider's regulation in 2012, it contained no

\footnotetext{
${ }^{12}$ The differences to the previous proposal were lower maximum tax deductions and the compulsory nature of these regulations for the federation and the cantons.

${ }^{13}$ The newspaper search is documented in Appendix $\mathrm{C}$
} 
amendments to withdrawal conditions apart from a minor increase in the fee (of CHF 100). Indirectly, one aspect of the previous regulations for our pension provider could have led to a systematic increase in withdrawals before 2011: Under the old rules, individuals could only choose between two cash out options in case they did not opt for full annuitization: either a small fraction of up to $25 \%$ or the entire capital (100\%). The withdrawal option opened up a possibility to circumvent this constraint. Recall that pension savings can also be used to reduce the mortgage of owner-occupied housing. For individuals close to retirement, paying back a certain fraction of their mortgage allowed them to cash out more than $25 \%$ but less than $100 \%$ of their second pillar retirement savings. While the more liberal cash out policy came into effect only in 2012, there was no evident reason to choose the cumbersome circumvention as soon as the change was announced in 2010. Thus, we expect a level effect from mid-2010 (or, taking into account time lags, from 2011) onwards, but no systematic change around the reform 14

\footnotetext{
${ }^{14}$ In a robustness check, we run the same regression for individuals aged 55 and lower, for whom an advance withdrawal to circumvent the cash out constraint at retirement is not financially attractive (cf. Table 10 in Appendix B.
} 
Table 2: BALANCE TEST — UNBALANCED SAMPLE

\begin{tabular}{lccccc}
\hline \hline & 2011 & 2013 & Diff. & SE & p-value \\
\hline Conditional on withdrawal & & & & & \\
Withdrawal amount in CHF 1,000 & 73.04 & 72.91 & -0.127 & 5.769 & 0.982 \\
Withdrawal share of pension assets & 0.67 & 0.65 & -0.019 & 0.027 & 0.480 \\
Constraint: CHF 10,000 (\%) & 37.72 & 36.78 & -0.938 & 4.880 & 0.848 \\
& & & & & \\
Observations & 228 & 174 & & & \\
\hline \hline Full sample & & & & & \\
Withdrawal (binary, \%) & 0.77 & 0.57 & -0.197 & 0.066 & 0.003 \\
Pledge (binary, \%) & 0.20 & 0.13 & -0.074 & 0.033 & 0.026 \\
\hline Age & 45.61 & 45.87 & 0.258 & 0.075 & 0.001 \\
Female (\%) & 53.00 & 53.45 & 0.451 & 0.406 & 0.267 \\
Married (\%) & 64.47 & 61.60 & -2.867 & 0.393 & 0.000 \\
Income in CHF 1,000 & 67.28 & 68.11 & 0.832 & 0.267 & 0.002 \\
Pension assets in CHF 1,000 & 157.59 & 163.41 & 5.824 & 1.521 & 0.000 \\
\hline Condominium price index & 156.83 & 175.40 & 18.573 & 0.319 & 0.000 \\
Single-family home price index & 144.19 & 157.77 & 13.575 & 0.250 & 0.000 \\
Income tax rate (\%) & 11.26 & 11.54 & 0.284 & 0.044 & 0.000 \\
Capital tax rate (\%) & 4.51 & 4.48 & -0.031 & 0.013 & 0.016 \\
Urban & 2.29 & 2.29 & 0.005 & 0.009 & 0.572 \\
& & & & & \\
Observations & 29,758 & 30,562 & & & \\
\hline \hline
\end{tabular}

Note: Balance test of the sample comparing the means of some main characteristics of individuals by year of observation (2011 vs. 2013). Based on individual-level data from a pension provider in 2011 and 2013. The sample is unbalanced and sample sizes are 29,758 for the 2011 and 30,562 for the 2013 observation samples. Withdrawal and pledge shares are calculated as the number of withdrawals/pledges of the total sample per year of observation. Withdrawal amount and share of pension assets are conditional on withdrawing money from the pension assets for real estate purchase. Conditional on a withdrawal, sample sizes are 228 for the 2011 and 174 for the 2013 observation samples. The capital tax rate corresponds to the specific tax rate that applies to the amount withdrawn from the individual pension account for a real estate purchase. For the non-withdrawers, it is calculated based on an assumed withdrawal of the mean share of $67 \%$ of pension wealth in advance. 


\section{Results}

\subsection{Aggregated data: descriptive evidence}

Figure 2 shows the aggregate number of advance withdrawals in the sample ${ }^{15}$ The reform took place in the middle of 2012. Accordingly, this year cannot be assigned to either the preor post-reform period. To estimate linear trends, we therefore omit this data point.

There is a decreasing trend in the number of advance withdrawals by year prior to the reform. The number of withdrawals drops from almost 300 in 2011 to about 250 after the reform in 2013. After 2013, the number of advance withdrawals remains relatively stable at around 250 per year. Generally, the downward trend prior to the reform is likely caused by rising house prices fuelled by historically low interest rates and high demand (cf. Figure 15 in Appendix B). While a lower interest rate lessens the mortgage installments (cf. Figure 13 in Appendix B , higher prices make the purchase of real estate more difficult financially for many due to higher capital needs. However, data before 2010 are difficult to interpret, as the pension provider had a restrictive cash out policy before the change in regulation of 2012. There is a marked decrease in withdrawals already observed between 2010 and 2011 - a likely effect of the announcement of a more liberal cash out policy. For identification purposes, if at all, the dip between 2010 and 2011 may lead to an under-estimation of the true effect of the reform. To assess the robustness of our assumption, we run the regressions for younger individuals only (for whom the circumvention was not attractive).

Conditional on choosing the option, the average amount withdrawn had been increasing throughout the pre-reform period and reached more than CHF 70,000 in 2011 (cf. Figure 3) ${ }^{16}$ The amount declined to around CHF 65,000 in 2012. Comparing the amounts withdrawn in the years adjacent to the reform suggests only a small effect relative to the mean. While a discontinuity in the amount withdrawn around the reform is hard to detect, 2012 marks the beginning of a decreasing trend following the reform. Due to limited data availability,

\footnotetext{
${ }^{15}$ Note that here we are drawing on data from the annual report of the pension provider, where no sample selection took place. Hence, numbers may not fully coincide with the descriptives presented in Table 2

${ }^{16}$ Note that here we are drawing on data from the universe of all advance withdrawers of the pension provider. Other than restricting the analysis to Swiss residents, no sample selection took place. Hence, numbers may not fully coincide with the descriptive statistics presented in Table 2
} 
FIG. 2: NuMBER OF ADVANCE WITHDRAWALS BY YEAR

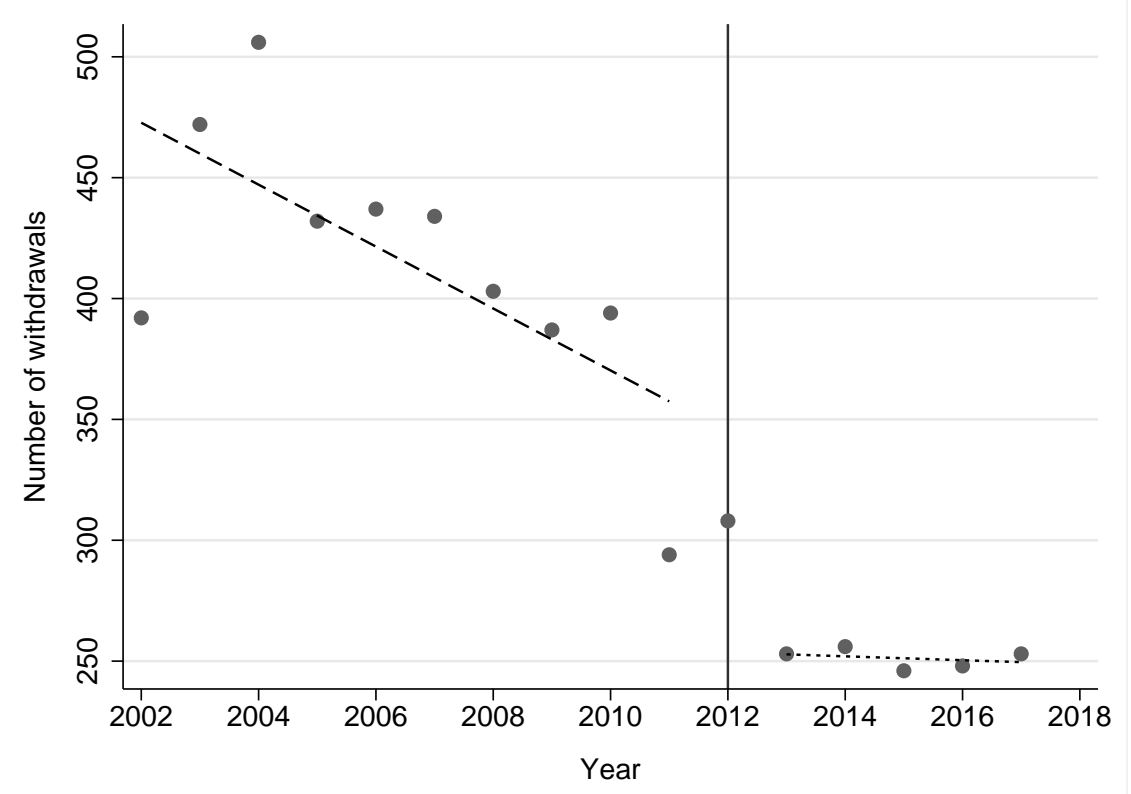

Note: Number of advance withdrawals from the second pillar for home ownership by year of withdrawal between 2002 and 2017. The vertical line depicts the reform date. Data stem from the annual report of the pension provider.

we cannot make statements about the share of pension assets withdrawn over a longer time period.

A possible issue is the external validity of our results, since our analysis draws on data from one specific pension provider. To demonstrate that our results are fairly representative for Switzerland, we compare the development over time between our pension provider data and aggregate Swiss statistics on advance withdrawals in Switzerland around the reform in 2012. For both Switzerland in total and the pension provider, we observe a decreasing trend in the number of withdrawals prior to the reform (cf. Figure 1). In 2011, the number of advance withdrawals was around 26,000. For our pension provider it was close to 300 . Considering that our pension provider covers approximately $1.1 \%$ of the Swiss labor force, the insured persons observed are representative of others in Switzerland. We also find a discontinuity of a similar relative magnitude around the reform in both cases: With stricter equity rules, fewer individuals withdraw money from their pension account for real estate purchase. 
FIG. 3: Average advance withdrawals

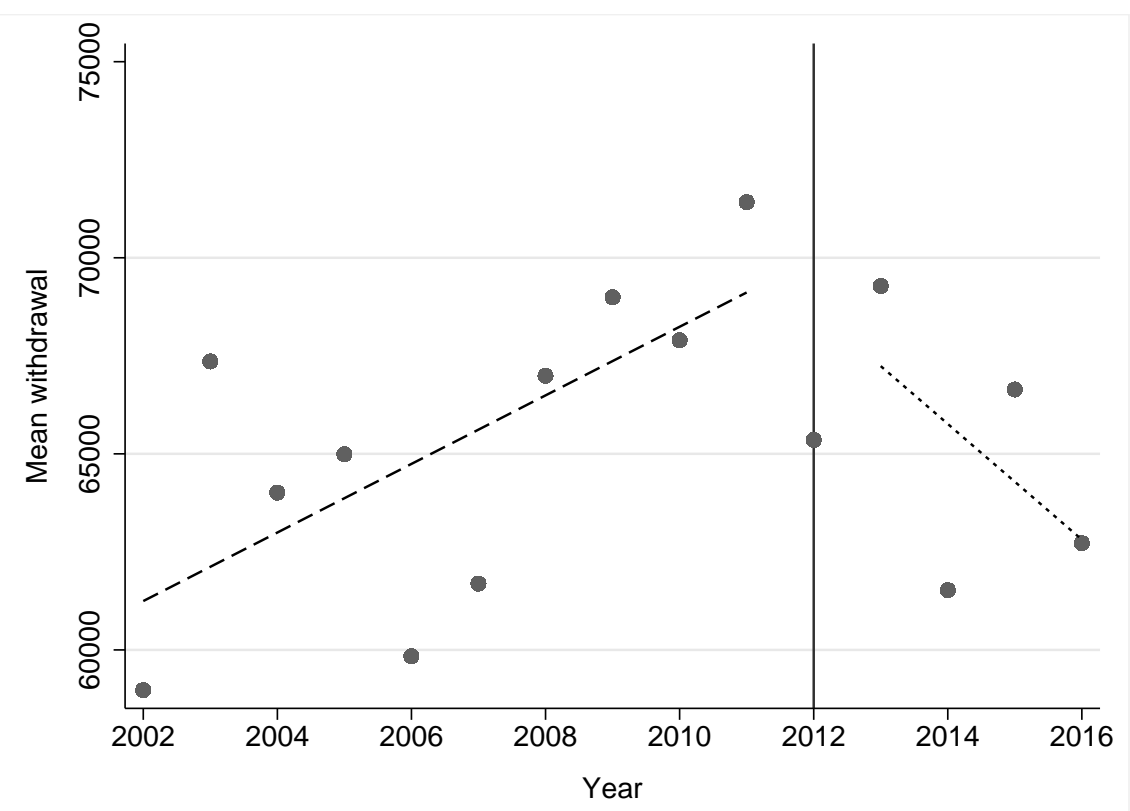

Note: Mean amount of advance withdrawal for home ownership from the second pillar by year of withdrawal. The vertical line depicts the reform date. Data stem from the pension provider. 


\subsection{Evidence of the effect of the reform from individual-level data}

In this section we provide individual-level evidence for the probability to withdraw pension assets for real estate purchase, and the share of assets withdrawn. On the intensive margin we are interested in the amount withdrawn and the share of pension assets claimed. We also run a regression on the share of individuals withdrawing the maximum possible amount from their pension wealth. The latter outcome variable does not only measure the degree to which pension wealth is the constraining factor, but also gives an indicator of how much it was the stricter down payment regulation that affects home purchases.

The first set of results concerns the probability to withdraw pension assets and can be found in Table 3$]\left.^{17}\right|^{8}$ Standard errors are clustered at the individual level, since observations of the same individual are correlated. We focus on individuals with at least CHF 20,000 in pension assets, which corresponds to the minimum withdrawal amount. We further focus on individuals who have not withdrawn pension assets in advance for home ownership in the five years prior to 2011 and are thus eligible to withdraw. In a first step, we also exclude individuals with residence abroad. Although the advance withdrawal may be used to finance home ownership abroad (i.e., for cross-border commuters), the guidelines of the stricter equity regulation apply to Swiss banks only. Columns (1)-(4) of Table 3 are based on an unbalanced sample including those who are observed alone in either 2011 or 2013. Column (1) presents a "raw" regression for the full sample without control variables. In column (2) we control for individual characteristics and in column (3) we additionally condition on non-missing regional covariates. Our baseline result is presented in column (4), where we control for individual and regional covariates.

The effect of the reform is significant across all specifications. Control variables, both individual and municipal, do not affect the reform coefficient. Results confirm the finding from the descriptive analysis that individuals are less likely to withdraw pension assets. For

\footnotetext{
${ }^{17}$ Using a probit or logit specification instead of a linear probability regression provides very similar results (cf. Tables 12 and 13 in Appendix B).

${ }^{18}$ Since less than $1 \%$ of the sample withdraws pension assets in advance, we attempt to predict the probability of a relatively rare event (King and Zeng, 2001). In order to test if the results from the logit specification are biased given such rarity, we also present results using a Firth logistic penalized maximum likelihood regression (Firth, 1993). Results remain robust and thus small sample bias does not seem to be a problem in the present case (cf. Table 14 in Appendix B).
} 
all specifications, the probability to claim pension assets decreases between 0.12 and 0.18 percentage points, ceteris paribus. This reduction is sizable in economic terms, considering a pre-reform level of $0.77 \%$ (cf. Table 2).

The probability of withdrawing assets is related to a number of factors. Compared to the reference age group of 60 and above, there is a positive relationship with the probability of withdrawing assets for all other age groups. Individuals aged 35-39 exhibit the strongest positive relation and are thus most likely to claim pension assets in advance. The probability of making an advance withdrawal is negatively related to being female and positively related to being married. These observations concur with a decreasing probability to transition from renting to owning for females (Angelini et al., 2014) and an increasing probability to become a home owner for married individuals (Angelini et al., 2014; Bourassa, 2015; Chiuri \& Jappelli, 2010). Interestingly, neither annual income nor pension wealth have a significant relation to the probability of withdrawing pension assets. This is an indication that the goal of the policy to facilitate home ownership for a wide range of incomes seems to be met.

As for regional factors, the likelihood to claim pension assets in advance is positively related to condominium prices and the degree of urbanity, but significantly negatively correlated with single-family house prices. In high price regions, individuals seem to substitute single-family homes for condominiums (cf. Figure 15 in Appendix B). The probability of withdrawing assets is significantly negatively related to capital tax rates. High capital tax rates (which are applied to cash outs regardless of their purpose) make advance withdrawals less attractive relative to other forms of capital. However, the probability of an advance withdrawal is not significantly related to income tax rates. This is intuitive, as a house purchase barely changes home owners' income. While mortgage interests can be deducted from taxable income, the imputed rental value of the house counts as income. Typically, the two factors offset each other to a high degree in case of a high loan-to-value ratio.

Regarding the change in the pension fund regulation of 2012, we run the same regression for individuals aged 55 and lower, for whom an advance withdrawal to circumvent the cash out constraint at retirement is not financially attractive, and find that our results on the extensive margin are robust. Comparing the results of the entire sample in Table 3 with the restricted sample of individuals aged 55 and below in Table 10 in Appendix B, we see that 
the raw effect (column (1)) is of the same magnitude. Results are also robust when including individual and regional controls (columns (2)-(4)). As a further robustness check, we run the same regression with foreign residents alone. Our implicit assumption is that residence in Switzerland serves as a proxy for mortgage contracts with Swiss banks. Comparative results to the sample of Swiss residents presented in a coefficient plot in Figure 7 in Appendix $\mathrm{B}$ show that the probability of advance withdrawals for foreign residents does not change significantly with the reform.

Next, we concentrate on individuals who have withdrawn pension assets and check whether the share of pension assets claimed and the absolute withdrawals have changed with the reform (cf. Tables 5 and 6, respectively). Since we are now conditioning on an advance withdrawal given that the probability to withdraw changed with the reform, our sample likewise changes 19 To provide evidence for the characteristics of individuals who withdrew pension money before and after the reform, we conduct t-tests for all control variables (cf. Table 4). The only significantly different individual characteristic is age: After the reform individuals who withdraw pension money are 1.5 years younger compared to those who claimed funds before the reform. In Section 5, we show that the reduction in withdrawals is mostly driven by older individuals. In terms of selection, those who claim assets after the reform must be younger on average.

A way to determine whether changes in the composition of those who withdraw pension assets derive from the reform, is to look at pre-trends in observables. The characteristics of individuals who withdraw assets should be relatively time-invariant before the reform. Due to limited data availability, our analysis of pre-trends is restricted, but we observe that the female share, the age at withdrawal and the share of advance withdrawal by geographical region are relatively time-invariant before the reform ${ }^{20}$

Based on the sample selection of advance withdrawers around the reform, we expect a compositional effect. Indeed, if we control for nothing else, we find no change with the reform

\footnotetext{
${ }^{19}$ In terms of interpretation, the intensive margin results are estimated for a selected sample and are only valid for this subpopulation.

${ }^{20}$ For the pre-treatment analysis we draw from the second dataset on the universe of all advance withdrawals from the pension provider between 2002 and 2017, which is incomplete and potentially biased prior to 2011 (cf. Figure 10 in Appendix B. Attrition rates are most likely higher for females and younger individuals due to shorter job tenure for earlier data points.
} 
(column (1) in Table 5). This is a striking finding given that the share of the typical $20 \%$ down payment requirement was halved. However, as soon as covariates are included, the effect of the reform turns significantly negative, i.e., individuals who claim pension assets take a smaller share of their funds. Depending on the specification, the effect varies between 4.2 and 5.6 percentage points (columns (2)-(4) in Table 5). Compared to the pre-reform average of $67.3 \%$, the reform has an economically significant effect on the share of funds used.

Not surprisingly given the shorter accumulation period, the share of pension assets withdrawn is higher for younger individuals. The relation between the share of pension assets withdrawn and income as well as the share of pension assets withdrawn and pension wealth is negative. Given the level of pension wealth (which is a good proxy for past income), higher wages hint at a more upward sloping wage profile. The latter can be viewed as an indication for a better financial situation overall and thus the availability of alternative means to finance the down payment. The withdrawal as a share of pension wealth is not significantly related to gender or marital status.

In terms of regional characteristics, we find that the withdrawn share is not significantly related to condominium prices, but positively to single-family houses, which are more expensive on average (cf. Figure 15 in Appendix B). The hard equity rule may be more binding for the latter.

Interestingly, the relationship between the share of pension wealth withdrawn and the capital tax rates is strong and significant. One potential explanation would be that those who face a larger tax bill need more capital to offset those tax costs. As the latter must be paid for by financial means outside the second pillar, it reduces available non-pension wealth (income effect dominating substitution effect).

As a robustness check, we also run the regression on the intensive margin for individuals aged 55 and younger alone. In this younger sample, we find no significant effect of the reform on the share of pension wealth withdrawn when controlling for individual and regional covariates (cf. Table 11 in Appendix B). This observation suggests that the effect of the reform on the intensive margin is driven by older individuals, who have more pension wealth on average. This implies that the hard equity constraint is binding.

Whereas the relative share of pension wealth decreases significantly after the reform, the 
withdrawal amount is unaffected by the reform (cf. Table 6). This deviation may be explained by differences in the withdrawal amount by pension wealth. If the wealthier individuals (who generally withdraw a smaller fraction of their pension wealth) withdraw a little more pension assets in advance and the poorer individuals (who often withdraw their entire available pension assets) withdraw a little less after the reform, the average amount withdrawn does not change significantly, yet the relative share of funds withdrawn decreases (cf. Figure 19 in Appendix B.

\subsection{Validity of identifying assumptions}

A central requirement for the validity of the identification strategy is that no relevant determinant of home ownership changes discontinuously with the reform.

Two of the most crucial macroeconomic variables that affect owner-occupied housing, and thus possibly advance withdrawals, are wages (Andrews \& Sánchez, 2011; Angelini et al., 2014; Gyourko \& Linneman, 1997; Turner \& Smith, 2009) and the unemployment rate (Chiuri and Jappelli, 2010). Neither annual real wages nor quarterly unemployment rates have discontinuities around the reform date (cf. Figures 11 and 12 in Appendix B.

Moreover, interest rates directly affect the cost of borrowing and thus the decision to purchase real estate. We inspect the interest rates for fixed mortgages and the Libor (3M) mortgage for 3 and 5 years ${ }^{21}$ (cf. Figure 13 in Appendix B). While there is an overall decreasing trend since the financial crisis, there are no distinct jumps around 2012 that could explain our findings.22

Household composition (Angelini et al., 2014, Bourassa et al., 2015; Chiuri \& Jappelli, 2010 Hilber, 2007) has been found to determine the home ownership rate. Being married (Angelini et al., 2014; Bourassa, 2015; Chiuri \& Jappelli, 2010) and children nest-leaving (Angelini et al., 2014) are positively related to the home ownership rate. We do not observe the household composition or marital status of our sample over an extensive time period.

${ }^{21}$ Of the private households who hold a mortgage, $56 \%$ do so with a remaining duration of $1-5$ years between 2009 and 2017 in Switzerland (Swiss National Bank 2018a)

${ }^{22}$ In October 2008 interest rates dropped dramatically because of central banks' attempt to stimulate aggregate demand in light of the financial crisis. The peak around May/June of 2011 just precedes the SNB's introduction of a minimum exchange rate of CHF 1.20 against the Euro on September 6, 2011. 
Moreover, there were no legal changes to marital or divorce rules around the reform date, which could have impacted the share of married individuals in Switzerland.

Finally, real estate prices play a direct role in the decision to own a home (Andrews \& Sánchez, 2011; Chiuri \& Japelli, 2003). We control for single-family home and condominium prices at the regional level in our regressions. Real estate prices have been rising since $200 \sqrt{23}$ (cf. Figure 15 in Appendix B), most likely due to high demand in view of high immigration rates as well as to low interest rates (cf. Figure 13 in Appendix B). Unattractive alternative investments and rising real incomes (cf. Figure 11 in Appendix B) are further reasons for a high real estate demand. Given the high real estate demand in Switzerland, the large increase in domestic mortgage claims comes as no surprise (cf. Figure 14 in Appendix B). However, there are no discontinuities around the reform date.

${ }^{23}$ Our single-family home and condominium transaction price index data from Wüst Partner only begin in 2007. 
Table 3: Main Results: Withdrawal probability Decreases

\begin{tabular}{|c|c|c|c|c|}
\hline VARIABLES & $\begin{array}{c}\text { (1) } \\
\text { Raw } \\
\end{array}$ & $\begin{array}{c}(2) \\
\text { Individual } \\
\text { controls }\end{array}$ & $\begin{array}{c}\text { (3) } \\
\text { Individual } \\
\text { controls }\end{array}$ & $\begin{array}{c}\text { (4) } \\
\text { Baseline }\end{array}$ \\
\hline Reform & $\begin{array}{c}-0.0013^{* *} \\
(0.0006)\end{array}$ & $\begin{array}{c}-0.0012^{*} \\
(0.0006)\end{array}$ & $\begin{array}{c}-0.0018^{* * *} \\
(0.0007)\end{array}$ & $\begin{array}{c}-0.0014^{* *} \\
(0.0007)\end{array}$ \\
\hline Age: $25-29 y$. & & $\begin{array}{c}0.0022 \\
(0.0015)\end{array}$ & $\begin{array}{c}0.0021 \\
(0.0017)\end{array}$ & $\begin{array}{c}0.0019 \\
(0.0016)\end{array}$ \\
\hline Age: $30-34 y$. & & $\begin{array}{c}0.0074^{* * *} \\
(0.0014)\end{array}$ & $\begin{array}{c}0.0069^{* * *} \\
(0.0015)\end{array}$ & $\begin{array}{c}0.0068^{* * *} \\
(0.0015)\end{array}$ \\
\hline Age: $35-39 y$. & & $\begin{array}{c}0.0114^{* * *} \\
(0.0014)\end{array}$ & $\begin{array}{c}0.0110^{* * *} \\
(0.0016)\end{array}$ & $\begin{array}{c}0.0110^{* * *} \\
(0.0016)\end{array}$ \\
\hline Age: $40-44 y$. & & $\begin{array}{c}0.0082^{* * *} \\
(0.0012)\end{array}$ & $\begin{array}{c}0.0072^{* * *} \\
(0.0013)\end{array}$ & $\begin{array}{c}0.0072^{* * *} \\
(0.0013)\end{array}$ \\
\hline Age: $45-49 y$. & & $\begin{array}{c}0.0075^{* * *} \\
(0.0011)\end{array}$ & $\begin{array}{c}0.0073^{* * *} \\
(0.0012)\end{array}$ & $\begin{array}{c}0.0072^{* * *} \\
(0.0012)\end{array}$ \\
\hline Age: $50-54 y$. & & $\begin{array}{c}0.0038^{* * *} \\
(0.0009)\end{array}$ & $\begin{array}{c}0.0032^{* * *} \\
(0.0009)\end{array}$ & $\begin{array}{c}0.0032^{* * * *} \\
(0.0009)\end{array}$ \\
\hline Age: $55-59 y$. & & $\begin{array}{c}0.0025^{* * *} \\
(0.0008)\end{array}$ & $\begin{array}{c}0.0021^{* *} \\
(0.0009)\end{array}$ & $\begin{array}{c}0.0020^{* *} \\
(0.0009)\end{array}$ \\
\hline Female & & $\begin{array}{c}-0.0021^{* * *} * \\
(0.0007)\end{array}$ & $\begin{array}{c}-0.0023^{* * *} \\
(0.0008)\end{array}$ & $\begin{array}{c}-0.0022^{* * *} \\
(0.0008)\end{array}$ \\
\hline Married & & $\begin{array}{c}0.0026^{* * *} \\
(0.0006)\end{array}$ & $\begin{array}{c}0.0030^{* * *} \\
(0.0007)\end{array}$ & $\begin{array}{c}0.0028^{* * *} \\
(0.0007)\end{array}$ \\
\hline Income in $\mathrm{CHF} 10,000$ & & $\begin{array}{c}0.0000 \\
(0.0002)\end{array}$ & $\begin{array}{c}0.0001 \\
(0.0002)\end{array}$ & $\begin{array}{c}0.0001 \\
(0.0002)\end{array}$ \\
\hline Pension assets in CHF 100,000 & & $\begin{array}{c}0.0001 \\
(0.0003)\end{array}$ & $\begin{array}{c}0.0001 \\
(0.0003)\end{array}$ & $\begin{array}{c}0.0002 \\
(0.0003)\end{array}$ \\
\hline Condominium & & & & $\begin{array}{c}0.0000^{* *} \\
(0.0000)\end{array}$ \\
\hline Single-family house & & & & $\begin{array}{c}-0.0001^{* * *} \\
(0.0000)\end{array}$ \\
\hline Income tax rate & & & & $\begin{array}{c}0.0001 \\
(0.0070)\end{array}$ \\
\hline Capital tax rate & & & & $\begin{array}{c}-0.0572^{* *} \\
(0.0267)\end{array}$ \\
\hline Urban & & & & $\begin{array}{c}0.0009^{* *} \\
(0.0004)\end{array}$ \\
\hline Constant & $\begin{array}{c}0.0075^{* * *} \\
(0.0005)\end{array}$ & $\begin{array}{c}0.0005 \\
(0.0012)\end{array}$ & $\begin{array}{c}0.0009 \\
(0.0013)\end{array}$ & $\begin{array}{c}0.0076^{* *} \\
(0.0030)\end{array}$ \\
\hline Observations & 67,503 & 67,503 & 60,320 & 60,320 \\
\hline Adjusted R-squared & 0.0000 & 0.0018 & 0.0020 & 0.0026 \\
\hline
\end{tabular}

Note: ${ }^{* * *} \mathrm{p}<0.01,{ }^{*} \mathrm{p}<0.05,{ }^{*} \mathrm{p}<0.1$. OLS regressions. The dependent variable is the probability to withdraw pension assets in advance. Standard errors are clustered at the individual level. Columns (1)-(4) are based on an unbalanced sample including those who are observed only in either 2011 or 2013. The reference age group is $\geq 60$ years. The capital tax rate is conditional on the withdrawal amount. For non-withdrawers, it is calculated based on an assumed withdrawal of the mean share of $67 \%$ of pension wealth in advance. 


\section{Table 4: Descriptive STATistiCs By YeAR OF WITHDRAWAL}

\begin{tabular}{lccccc}
\hline \hline & Withdrawal 2011 & Withdrawal 2013 & Diff. & SE & p-value \\
\hline Withdrawal amount in CHF 1,000 & 73.04 & 72.91 & -0.127 & 5.769 & 0.982 \\
Withdrawal share of pension assets & 0.67 & 0.65 & -0.019 & 0.027 & 0.480 \\
Constraint: CHF 10,000 (\%) & 37.72 & 36.78 & -0.938 & 4.880 & 0.848 \\
Pledge (binary, \%) & 3.51 & 2.87 & -0.635 & 1.785 & 0.722 \\
\hline Age at withdrawal & 43.65 & 42.11 & -1.539 & 0.770 & 0.047 \\
Female (\%) & 41.67 & 42.53 & 0.862 & 4.981 & 0.863 \\
Married (\%) & 75.00 & 71.84 & -3.161 & 4.444 & 0.477 \\
Income in CHF 1,000 & 69.95 & 73.26 & 3.309 & 3.220 & 0.305 \\
Pension assets in CHF 1,000 & 144.99 & 139.90 & -5.090 & 17.654 & 0.773 \\
\hline Condominium price index & 151.13 & 166.38 & 15.246 & 3.522 & 0.000 \\
Single-family home price index & 137.37 & 150.05 & 12.679 & 2.728 & 0.000 \\
Income tax rate (\%) & 11.37 & 11.50 & 0.132 & 0.523 & 0.800 \\
Capital tax rate (\%) & 4.30 & 4.11 & -0.191 & 0.143 & 0.182 \\
Urban & 2.50 & 2.51 & 0.007 & 0.115 & 0.951 \\
& & & & & \\
Observations & 228 & 174 & & & \\
\hline \hline
\end{tabular}

Note: Descriptive statistics and t-tests of the sample comparing the means of the main individual characteristics of withdrawers in 2011 (Withdrawal 2011) with withdrawers in 2013 (Withdrawal 2013). Based on individual-level data from a pension provider in 2011 and 2013. Standard errors are clustered at the individual level. 
Table 5: MAin Results: WithdraWAL Share DECREASES

\begin{tabular}{|c|c|c|c|c|}
\hline VARIABLES & $\begin{array}{r}\text { (1) } \\
\text { Raw }\end{array}$ & $\begin{array}{c}(2) \\
\text { Individual } \\
\text { controls }\end{array}$ & $\begin{array}{c}(3) \\
\text { Individual } \\
\text { controls }\end{array}$ & $\begin{array}{c}\text { (4) } \\
\text { Baseline }\end{array}$ \\
\hline Reform & $\begin{array}{l}-0.0283 \\
(0.0253)\end{array}$ & $\begin{array}{c}-0.0561^{* * *} \\
(0.0214)\end{array}$ & $\begin{array}{c}-0.0421^{*} \\
(0.0233)\end{array}$ & $\begin{array}{c}-0.0505^{* *} \\
(0.0240)\end{array}$ \\
\hline Age: $25-29 y$. & & $\begin{array}{c}0.5881^{* * *} \\
(0.0749)\end{array}$ & $\begin{array}{c}0.6050^{* * *} * \\
(0.0752)\end{array}$ & $\begin{array}{c}0.5615^{* * *} \\
(0.0549)\end{array}$ \\
\hline Age: $30-34 y$. & & $\begin{array}{c}0.5562^{* * * *} \\
(0.0667)\end{array}$ & $\begin{array}{c}0.5684^{* * *} \\
(0.0672)\end{array}$ & $\begin{array}{c}0.5320^{* * *} \\
(0.0517)\end{array}$ \\
\hline Age: $35-39 y$. & & $\begin{array}{c}0.4846^{* * *} \\
(0.0672)\end{array}$ & $\begin{array}{c}0.5113^{* * *} \\
(0.0671)\end{array}$ & $\begin{array}{c}0.4669^{* * *} \\
(0.0514)\end{array}$ \\
\hline Age: $40-44 y$. & & $\begin{array}{c}0.4111^{* * *} \\
(0.0679)\end{array}$ & $\begin{array}{c}0.4059^{* * *} \\
(0.0698)\end{array}$ & $\begin{array}{c}0.3657^{* * *} * \\
(0.0552)\end{array}$ \\
\hline Age: $45-49 y$. & & $\begin{array}{c}0.3572^{* * *} \\
(0.0665)\end{array}$ & $\begin{array}{c}0.3873^{* * *} \\
(0.0676)\end{array}$ & $\begin{array}{c}0.3325^{* * *} * \\
(0.0518)\end{array}$ \\
\hline Age: $50-54 y$. & & $\begin{array}{c}0.2253^{* * *} \\
(0.0658)\end{array}$ & $\begin{array}{c}0.2553^{* * *} \\
(0.0685)\end{array}$ & $\begin{array}{c}0.2013^{* * *} \\
(0.0518)\end{array}$ \\
\hline Age: $55-59 y$. & & $\begin{array}{l}0.1168^{*} \\
(0.0609)\end{array}$ & $\begin{array}{c}0.1296^{* *} \\
(0.0634)\end{array}$ & $\begin{array}{c}0.0892^{* *} \\
(0.0444)\end{array}$ \\
\hline Female & & $\begin{array}{c}0.0368 \\
(0.0235)\end{array}$ & $\begin{array}{c}0.0395 \\
(0.0252)\end{array}$ & $\begin{array}{c}0.0301 \\
(0.0259)\end{array}$ \\
\hline Married & & $\begin{array}{c}0.0173 \\
(0.0231)\end{array}$ & $\begin{array}{c}0.0232 \\
(0.0256)\end{array}$ & $\begin{array}{c}0.0048 \\
(0.0303)\end{array}$ \\
\hline Income in CHF 10,000 & & $\begin{array}{c}-0.0092^{*} \\
(0.0051)\end{array}$ & $\begin{array}{c}-0.0114^{* *} \\
(0.0053)\end{array}$ & $\begin{array}{c}-0.0100^{*} \\
(0.0058)\end{array}$ \\
\hline Pension assets in CHF 100,000 & & $\begin{array}{c}-0.0197^{*} \\
(0.0117)\end{array}$ & $\begin{array}{l}-0.0145 \\
(0.0113)\end{array}$ & $\begin{array}{c}-0.0190^{*} \\
(0.0113)\end{array}$ \\
\hline Condominium & & & & $\begin{array}{c}-0.0009 \\
(0.0008)\end{array}$ \\
\hline Single-family house & & & & $\begin{array}{c}0.0020^{*} \\
(0.0011)\end{array}$ \\
\hline Income tax rate & & & & $\begin{array}{c}-0.4670 \\
(0.2886)\end{array}$ \\
\hline Capital tax rate & & & & $\begin{array}{c}2.6811^{* * *} \\
(0.9096)\end{array}$ \\
\hline Urban & & & & $\begin{array}{l}-0.0012 \\
(0.0103)\end{array}$ \\
\hline Constant & $\begin{array}{c}0.6691 * * * \\
(0.0166)\end{array}$ & $\begin{array}{c}0.3573^{* * *} \\
(0.0705)\end{array}$ & $\begin{array}{c}0.3379^{* * *} \\
(0.0714)\end{array}$ & $\begin{array}{c}0.1973^{* *} \\
(0.0820)\end{array}$ \\
\hline Observations & 464 & 464 & 402 & 402 \\
\hline Adjusted R-squared & 0.0005 & 0.3433 & 0.3370 & 0.3642 \\
\hline
\end{tabular}

Note: ${ }^{* * *} \mathrm{p}<0.01, * * \mathrm{p}<0.05,{ }^{*} \mathrm{p}<0.1$. OLS regressions. The dependent variable is the share of pension assets claimed as advance withdrawal. Standard errors are clustered at the individual level. Columns (1)-(4) are based on an unbalanced sample of withdrawers in 2011 and 2013. Column (1) presents a "raw" regression. In column (2) we control for individual covariates. In column (3) we additionally condition on non-missing regional covariates. Column (4) presents the baseline, where we control for individual and regional covariates. The reference age group is $\geq 60$ years. 
Table 6: Main Results: WithdraWAl AMOUNT IS UNAFFECTED

\begin{tabular}{|c|c|c|c|c|}
\hline VARIABLES & $\begin{array}{l}\text { (1) } \\
\text { Raw }\end{array}$ & $\begin{array}{c}(2) \\
\text { Individual } \\
\text { controls }\end{array}$ & $\begin{array}{c}(3) \\
\text { Individual } \\
\text { controls }\end{array}$ & $\begin{array}{c}\text { (4) } \\
\text { Baseline }\end{array}$ \\
\hline Reform & $\begin{array}{l}-3.6667 \\
(5.2732)\end{array}$ & $\begin{array}{c}0.2852 \\
(3.8764)\end{array}$ & $\begin{array}{c}2.0644 \\
(4.3334)\end{array}$ & $\begin{array}{c}0.9500 \\
(4.1501)\end{array}$ \\
\hline Age: $25-29 y$. & & $\begin{array}{c}24.3697 \\
(28.0374)\end{array}$ & $\begin{array}{c}27.0384 \\
(28.7888)\end{array}$ & $\begin{array}{c}20.3782 \\
(24.0969)\end{array}$ \\
\hline Age: $30-34 y$. & & $\begin{array}{c}37.5184 \\
(27.6201)\end{array}$ & $\begin{array}{c}39.2857 \\
(28.3177)\end{array}$ & $\begin{array}{c}33.8059 \\
(22.3168)\end{array}$ \\
\hline Age: $35-39 y$. & & $\begin{array}{l}48.2983^{*} \\
(27.3701)\end{array}$ & $\begin{array}{l}51.7556^{*} \\
(27.9882)\end{array}$ & $\begin{array}{l}43.2942^{* *} \\
(21.9681)\end{array}$ \\
\hline Age: $40-44 y$. & & $\begin{array}{c}55.8232^{* *} \\
(27.0623)\end{array}$ & $\begin{array}{c}56.5334^{* *} \\
(27.6872)\end{array}$ & $\begin{array}{l}49.9730^{* *} \\
(21.5272)\end{array}$ \\
\hline Age: $45-49 y$. & & $\begin{array}{c}61.5431^{* *} \\
(26.8686)\end{array}$ & $\begin{array}{c}65.9916^{* *} \\
(27.4587)\end{array}$ & $\begin{array}{c}55.0634^{* *} \\
(21.3528)\end{array}$ \\
\hline Age: $50-54 y$. & & $\begin{array}{c}59.6243^{* *} \\
(27.3755)\end{array}$ & $\begin{array}{c}63.5663^{* *} \\
(28.2558)\end{array}$ & $\begin{array}{l}52.8451^{* *} \\
(22.3844)\end{array}$ \\
\hline Age: $55-59 y$. & & $\begin{array}{c}37.2199 \\
(26.9915)\end{array}$ & $\begin{array}{c}39.6243 \\
(27.9165)\end{array}$ & $\begin{array}{c}32.3481 \\
(21.2815)\end{array}$ \\
\hline Female & & $\begin{array}{l}6.3608^{*} \\
(3.8165)\end{array}$ & $\begin{array}{c}4.8869 \\
(3.9659)\end{array}$ & $\begin{array}{c}3.7435 \\
(4.0544)\end{array}$ \\
\hline Married & & $\begin{array}{l}-2.2996 \\
(4.1989)\end{array}$ & $\begin{array}{l}-3.7772 \\
(4.7759)\end{array}$ & $\begin{array}{l}-7.1139 \\
(5.1979)\end{array}$ \\
\hline Income in $\mathrm{CHF} 10,000$ & & $\begin{array}{c}4.0402^{* * *} \\
(1.0961)\end{array}$ & $\begin{array}{c}3.4000^{* * *} \\
(1.1440)\end{array}$ & $\begin{array}{c}3.9076^{* * *} \\
(1.2925)\end{array}$ \\
\hline Pension assets in CHF 100,000 & & $\begin{array}{c}18.0979 * * * \\
(3.6573)\end{array}$ & $\begin{array}{c}18.9240^{* * *} \\
(3.9491)\end{array}$ & $\begin{array}{c}17.8106^{* * *} \\
(3.9537)\end{array}$ \\
\hline Condominium & & & & $\begin{array}{c}-0.1293 \\
(0.1693)\end{array}$ \\
\hline Single-family house & & & & $\begin{array}{c}0.2958 \\
(0.2000)\end{array}$ \\
\hline Income tax rate & & & & $\begin{array}{c}-104.7561^{* *} \\
(46.7611)\end{array}$ \\
\hline Capital tax rate & & & & $\begin{array}{c}618.3212^{* * *} \\
(178.7462)\end{array}$ \\
\hline Urban & & & & $\begin{array}{c}-2.9708^{*} \\
(1.5923)\end{array}$ \\
\hline Constant & $\begin{array}{c}73.6663^{* * *} \\
(3.3409)\end{array}$ & $\begin{array}{l}-34.5200 \\
(28.1761)\end{array}$ & $\begin{array}{l}-32.4963 \\
(28.9912)\end{array}$ & $\begin{array}{c}-51.3043^{* *} \\
(26.0830)\end{array}$ \\
\hline Observations & 464 & 464 & 402 & 402 \\
\hline Adjusted R-squared & -0.0011 & 0.5068 & 0.5147 & 0.5442 \\
\hline
\end{tabular}

Note: ${ }^{* * *} \mathrm{p}<0.01,{ }^{* *} \mathrm{p}<0.05,{ }^{*} \mathrm{p}<0.1$. OLS regressions. The dependent variable is the amount of pension assets in CHF 1,000 claimed as advance withdrawal. Standard errors are clustered at the individual level. Columns (1)-(4) are based on an unbalanced sample of withdrawers in 2011 and 2013. Column (1) presents a "raw" regression. In column (2) we control for individual covariates. In column (3) we additionally condition on non-missing regional covariates. Column (4) presents the baseline, where we control for individual and regional covariates. The reference age group is $\geq 60$ years. 


\section{$5 \quad$ Heterogeneous effects and mechanisms}

Our results show that fewer individuals withdraw pension wealth for real estate purchases after the tightening of the equity requirements in 2012. Conditional on cashing-out, the amount withdrawn falls, albeit not by very much. While the reform had a decisive impact on withdrawal patterns, we cannot discern whether individuals withdrew because they did not meet the hard equity criterion imposed by the reform, or because they decided not to use pension wealth for other reasons. The more interesting question concerns the underlying mechanisms that can explain these findings. Potential mechanisms to explain the drop in the withdrawal rate and the size of the withdrawal after the reform are that the affected individuals abstain from purchasing real estate, postpone the purchase, find alternative equity, downsize by buying smaller and less expensive property.

In this Section, we assess the different underlying channels empirically. We investigate whether the effect of the reform varies by individually and regionally observable characteristics. We also analyze alternative sources of funding for real estate by looking at the share of individuals constrained by their maximum withdrawable pension assets and the option to pledge pension wealth. For the real estate channel, we look at the number of sales of singlefamily homes and condominiums in the canton of Zurich. For the downsizing channel, we look at the prices of real estate sold in the canton of Zurich as well as the number of rooms new home owners report in Switzerland. ${ }^{24}$ Zurich is Switzerland's largest canton, making up more than 17\% of the population (Federal Statistical Office, 2019a). Although Zurich's real estate prices are decidedly above the Swiss average, so is its GDP per capita, albeit not to the same degree.25

\subsection{Observable characteristics}

For the analysis of marginal effects of the reform, we focus on the observable characteristics that were significantly related to the measured effects of the reform on the extensive and

\footnotetext{
${ }^{24}$ These descriptive results do not control for the rising house prices in Switzerland.

${ }^{25}$ Whereas the average ask price of single-family homes (condominiums) in Zurich is 1.75 (1.96) times that of the Swiss average (Wüest Partner, 2019), Zurich's GDP per capita is 1.19 times the Swiss average GDP per capita (Federal Statistical Office, 2019a).
} 
intensive margins (cf. Tables 3 and 5), particularly age, income and pension wealth.

Considering the marginal effect of the reform by age, we find that the reduction in the probability of withdrawing funds and the share of funds withdrawn is driven mostly by older individuals (cf. Figure 20 in Appendix B). We cannot infer from the data whether elderly individuals were driven out of the market because they lacked alternative means to cover the hard equity requirement, or because they deliberately chose to cover the entire down payment from alternative means. The latter is less likely, as the withdrawal conditions were not affected by the reform. Younger individuals, on the other hand, may not be touched as much by the reform since they tend to have too little pension assets to cover more than $10 \%$ of the loan regardless of the down payment policy.

Our results suggest that lower- and middle-income individuals and those with lower levels of pension wealth were more strongly affected by the tightening of equity requirements. The decrease in the share of pension assets withdrawn is stronger for lower- and middle-income individuals, and is significant for annual incomes up to CHF 100,000 (cf. Figure 21 in Appendix B). Whereas income is just a snapshot of the present financial situation, pension wealth is a good proxy for past income. Likewise, the decrease in the share of pension assets withdrawn is stronger for individuals with lower levels of pension wealth, and is significant for pension wealths up to CHF 450,000 (cf. Figure 22 in Appendix B). Wealthier individuals likely possessed more additional means to finance real estate.

In sum, the new down payment policy made home purchases more difficult for more financially vulnerable individuals. While the policy change was mainly triggered by macroprudential concerns, there was also much public discussion around the vulnerability of home owners, especially in case of divorce and retirement. Even before the policy change, banks required mortgage holders to reduce their loan to two thirds of the house value at age 65 and to maintain an income high enough to be able to cover mortgage installments even at an implicit interest rate of $5 \%$. It is likely that the stricter down payment policy made it more difficult for elderly middle-income, asset poor households to purchase a home. Concomitantly, it might have reduced the danger of foreclosure for elderly households entering retirement. 


\subsection{Alternative sources of funding}

Potential new home owners may be forced to or deliberately choose alternative assets to cover the down payment. Other than withdrawing pension assets in advance, a new home may be financed by borrowing from other sources, such as relatives, or pledging pension wealth. Recall that equity from pillar 3a has always been a much more attractive way to tap into retirement savings to purchase a house (cf. Section 2.4). This leaves the relative advantage of third pillar financing over second pillar withdrawals unchanged.

Table 7: Mechanisms: SHARE OF INDIVIDUALS WITHDRAWING ENTIRE PENSION WEALTH DECREASES

\begin{tabular}{|c|c|c|c|c|}
\hline VARIABLES & Raw & $\begin{array}{c}(2) \\
\text { Individual } \\
\text { controls }\end{array}$ & $\begin{array}{c}(3) \\
\text { Individual } \\
\text { controls }\end{array}$ & Baseline \\
\hline Reform & $\begin{array}{l}-0.0350 \\
(0.0451)\end{array}$ & $\begin{array}{c}-0.0997^{* * *} \\
(0.0379)\end{array}$ & $\begin{array}{l}-0.0636 \\
(0.0419)\end{array}$ & $\begin{array}{c}-0.0803^{*} \\
(0.0432)\end{array}$ \\
\hline Individual controls & no & yes & yes & yes \\
\hline Regional controls & no & no & no & yes \\
\hline Constant & $\begin{array}{c}0.3843^{* * *} \\
(0.0303)\end{array}$ & $\begin{array}{c}0.1407 \\
(0.2126)\end{array}$ & $\begin{array}{c}0.0868 \\
(0.2187)\end{array}$ & $\begin{array}{c}0.0156 \\
(0.2562)\end{array}$ \\
\hline Observations & 464 & 464 & 402 & 402 \\
\hline Adjusted R-squared & -0.0009 & 0.3214 & 0.2994 & 0.2999 \\
\hline \multicolumn{5}{|c|}{$\begin{array}{l}\text { Note: } * * * \mathrm{p}<0.01,{ }^{* *} \mathrm{p}<0.05,{ }^{*} \mathrm{p}<0.1 \text {. OLS regressions. The } \\
\text { dependent variable is the share of pension assets claimed as ad- } \\
\text { vance withdrawal. Standard errors are clustered at the individual } \\
\text { level. Columns }(1)-(4) \text { are based on an unbalanced sample of } \\
\text { withdrawers in } 2011 \text { and } 2013 \text {. Column }(1) \text { presents a "raw" re- } \\
\text { gression. In column }(2) \text { we control for individual covariates. In } \\
\text { column (3) we additionally condition on non-missing regional } \\
\text { covariates. Column (4) presents the baseline, where we control } \\
\text { for individual and regional covariates. }\end{array}$} \\
\hline
\end{tabular}

Another way to examine at the importance of non-pension assets is to look at the constraining factor in the withdrawal decision. If the $10 \%$ hard equity regulation after the reform is the decisive constraint, we should observe not only a decrease in the amount withdrawn as a share of pension wealth (which we find), but also find fewer individuals constrained by the pension fund's withdrawal restriction (100\% up to age 50 and accumulated wealth at age 50 for those older). To account for the rounding of values, we define individuals to be constrained if the withdrawn amount is within CHF 10,000 of the maximum withdrawable 
pension assets. The binary variable Constraint: CHF 10,000 equals one, if the insured person withdraws her maximum eligible pension wealth less CHF 10,000.

The descriptive statistics in Table 2 show that the share of individuals withdrawing their maximum pension wealth did not change significantly with the reform. In Table 7 we further analyze the effect of the reform with a linear regression. As expected from the descriptive statistics, the raw effect is statistically insignificant. If we control for individual and regional covariates, the effect of the reform is associated with a reduction in the probability of withdrawing the maximum possible pension assets of 8.5 to 10 percentage points, ceteris paribus, depending on the specification.

Deviating from a pre-reform average of $37.7 \%$ of pension-wealth constrained individuals, this effect is also sizable in economic terms. Nonetheless, since pension savings account for a large fraction of middle-aged households' wealth on average, we would have seen an even larger decline, had the available pension wealth been the most important constraint. It seems that households find it more difficult to raise the $10 \%$ hard equity than tapping into their pension wealth to finance owner-occupied housing. Hence, while the reform tightened the constraint, $63.2 \%$ remain unaffected after the reform (because they do not claim the whole amount).

As a second channel to finance home ownership from pension assets, the individual may pledge pension wealth. Table 4 shows that the sample of advanced withdrawers does not coincide with the sample that pledges. Only 3.5\% of withdrawers in 2011 and $2.9 \%$ of withdrawers in 2013 also pledge their pension assets.

Since pledges do not count as equity, they were not directly reform-relevant. In some cases, however, banks have been willing to accept a loan-to-value ratio above $80 \%$ with a pledge on hand. This is due to the additional security and because a collateral can be interpreted as a favorable signal against the adverse selection of bad borrowers. Besides, the motivation of the reform emphasized the risk of an overheated property market and indebted households. Hence, although the reform did not impact the option to pledge directly, we expect repercussions if banks were more reluctant to accept pension wealth pledges for better borrowing conditions after the reform.

In Table 8 we show that the probability to pledge also decreases in response to the stricter 
Table 8: Mechanisms: Probability to Pledge Decreases

\begin{tabular}{|c|c|c|c|c|}
\hline VARIABLES & $\begin{array}{l}\text { (1) } \\
\text { Raw }\end{array}$ & $\begin{array}{c}(2) \\
\text { Individual } \\
\text { controls }\end{array}$ & $\begin{array}{c}(3) \\
\text { Individual } \\
\text { controls }\end{array}$ & $\begin{array}{c}\text { (4) } \\
\text { Baseline }\end{array}$ \\
\hline Reform & $\begin{array}{c}-0.0008^{* * *} \\
(0.0003)\end{array}$ & $\begin{array}{c}-0.0009^{* * *} \\
(0.0003)\end{array}$ & $\begin{array}{c}-0.0007^{* *} \\
(0.0003)\end{array}$ & $\begin{array}{c}-0.0005 \\
(0.0003)\end{array}$ \\
\hline Individual controls & no & yes & yes & yes \\
\hline Regional controls & no & no & no & yes \\
\hline Constant & $\begin{array}{c}0.0020^{* * *} * \\
(0.0002)\end{array}$ & $\begin{array}{c}-0.0020^{* *} \\
(0.0008)\end{array}$ & $\begin{array}{c}-0.0022^{* *} \\
(0.0009)\end{array}$ & $\begin{array}{c}-0.0014 \\
(0.0014)\end{array}$ \\
\hline Observations & 67,503 & 67,503 & 60,320 & 60,320 \\
\hline Adjusted R-squared & 0.0001 & 0.0021 & 0.0021 & 0.0026 \\
\hline
\end{tabular}

Note: $* * * \mathrm{p}<0.01,{ }^{*} * \mathrm{p}<0.05,{ }^{*} \mathrm{p}<0.1$. OLS regressions. The dependent variable is the probability to pledge pension wealth. Standard errors are clustered at the individual level. Columns (1)-(4) are based on an unbalanced sample including those who are observed only in either 2011 or 2013 . Column (1) presents a "raw" regression. In column (2) we control for individual covariates. In column (3) we additionally condition on non-missing regional covariates. Column (4) presents the baseline, where we control for individual and regional covariates.

equity guidelines. Depending on the specification, the probability to pledge decreases by 0.06 to 0.09 percentage points, ceteris paribus. Considering a pre-reform pledge probability of $0.21 \%$, this decrease is also sizable in economic terms (cf. Table 2 ).

\subsection{Purchasing real estate channel}

A further potential response to the reform is to postpone the purchase of a home until the equity requirement is met or to abstain from buying altogether. To investigate this underlying mechanism, we look at the annual number of households acquiring ownership as well as the number of real estate purchases.

First, we study how the number of households acquiring ownership changed around the reform date throughout Switzerland. Figure 4 depicts the number of moves by year for the two transitions of interest: a renter moving into owner-occupied housing (renter-owner) and an owner moving into another owner-occupied housing (owner-owner). With the reform, the number of moves drops for both transitions, suggesting a fall in the number of home purchases. This observed decline in home ownership transition in Switzerland is in line with 
a drop in home purchase transactions - both for condominiums and single-family homes between 2011 and 2013 (Swiss Real Estate Datapool, SRED) ${ }^{26}$

\section{FIG. 4: NUMBER OF MOVES INTO OWNERSHIP BY YEAR}

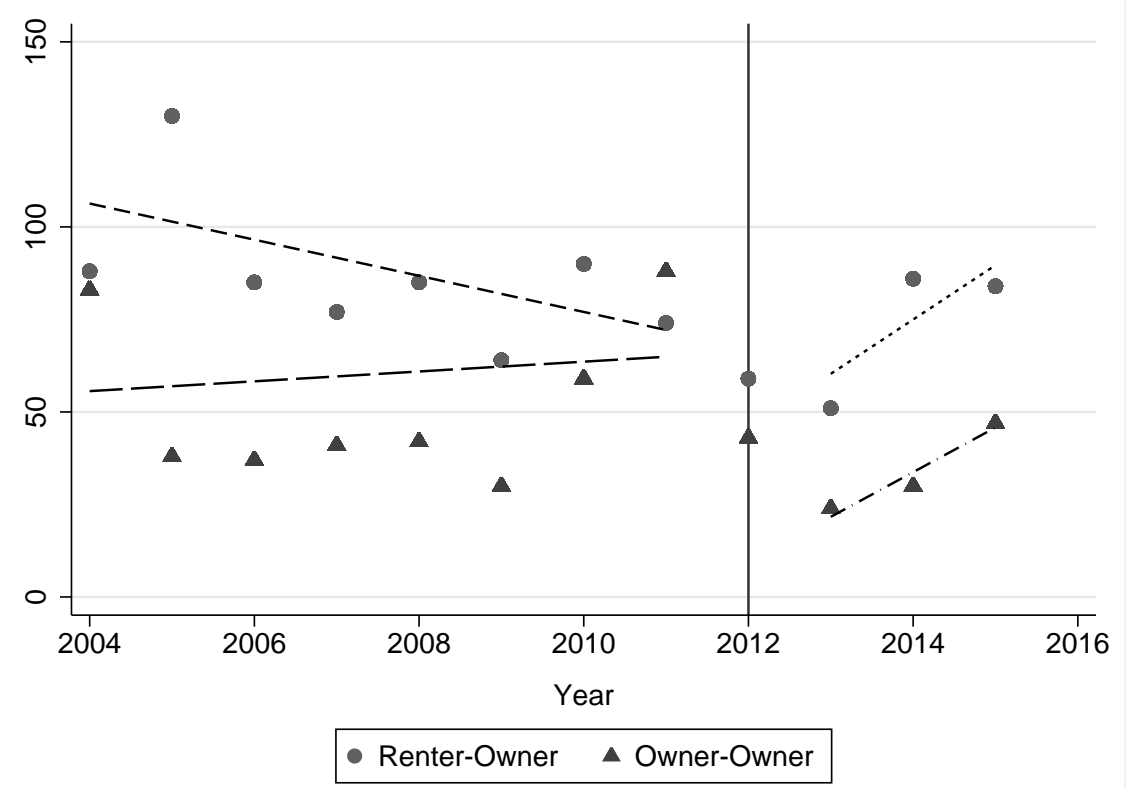

Note: Number of moves into ownership by year between 2004 and 2015. The vertical line depicts the reform date. Data stem from the Swiss Household Panel.

Second, we investigate the type of ownership by looking at the number of real estate purchases, this time using data from the canton of Zurich. Likewise exclusively for the canton of Zurich, we observe a drop in the total number of real estate purchases around the reform date (cf. Table 15 in Appendix B). The overall decrease in purchases is driven by sales of single-family homes (Figure 5), sales of condominiums being more volatile. The number of condominium purchases increased in the years adjacent to the reform, while the number of single-family home purchases decreased. This descriptive evidence confirms our assumption regarding the effect of the reform on the extensive margin (cf. Table 3). Especially in high price regions such as the canton of Zurich, individuals seem to substitute single-family homes for condominiums.

\footnotetext{
${ }^{26}$ The SRED dataset contains all transactions that were financed by Credit Suisse, UBS and the Zurich Cantonal Bank - three major banks in Switzerland. With 118,000 $(93,000)$ condominium (single-family home) transactions in the time period we study, the database should comprise approximately $35 \%$ of the transactions financed by mortgages in Switzerland.
} 
FIG. 5: Number of REAl Estate Purchases

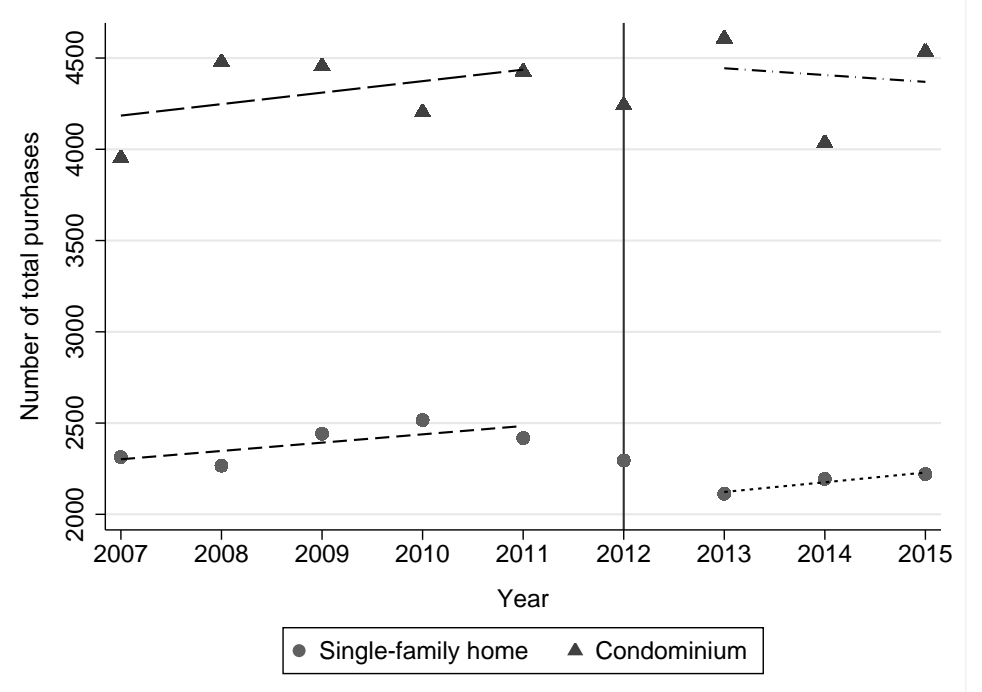

Note: Number of total single-family home and condominium purchases by year in the canton of Zurich between 2007 and 2015. The vertical line depicts the reform date. Data stem from the Statistical Office in the canton of Zurich.

\subsection{Downsizing channel}

Individuals may also start downsizing their owner-occupied housing as a response to the reform. At the aggregate level, we first analyze this possibility by looking at the number of rooms in new homes as a proxy. Subsequently, we explicitly analyze price changes of purchased real estate for one canton (Zurich) as an indicator of adjusted spending with the reform.

Figure 6 shows the number of rooms in a new home by year for the two transitions into ownership, i.e., renter-owner and owner-owner. In the two years adjacent to the reform year, the number of rooms drops for households moving from renting to owning from over 5 rooms to less than 4.5 rooms on average. This suggests that new home owners downsize their homes after the reform on average.

Inspecting the prices of purchased properties, we find no direct evidence of individuals choosing cheaper housing as a response to the stricter equity regulation. In Table 15 in Appendix B we present descriptive statistics of real estate purchases in the canton of Zurich, comparing the means of property and buyer characteristics in the years adjacent to the reform. The net prices paid for real estate between 2011 and 2013 increased significantly for 
FIG. 6: NuMBER OF ROOMS IN NEW HOME BY YEAR

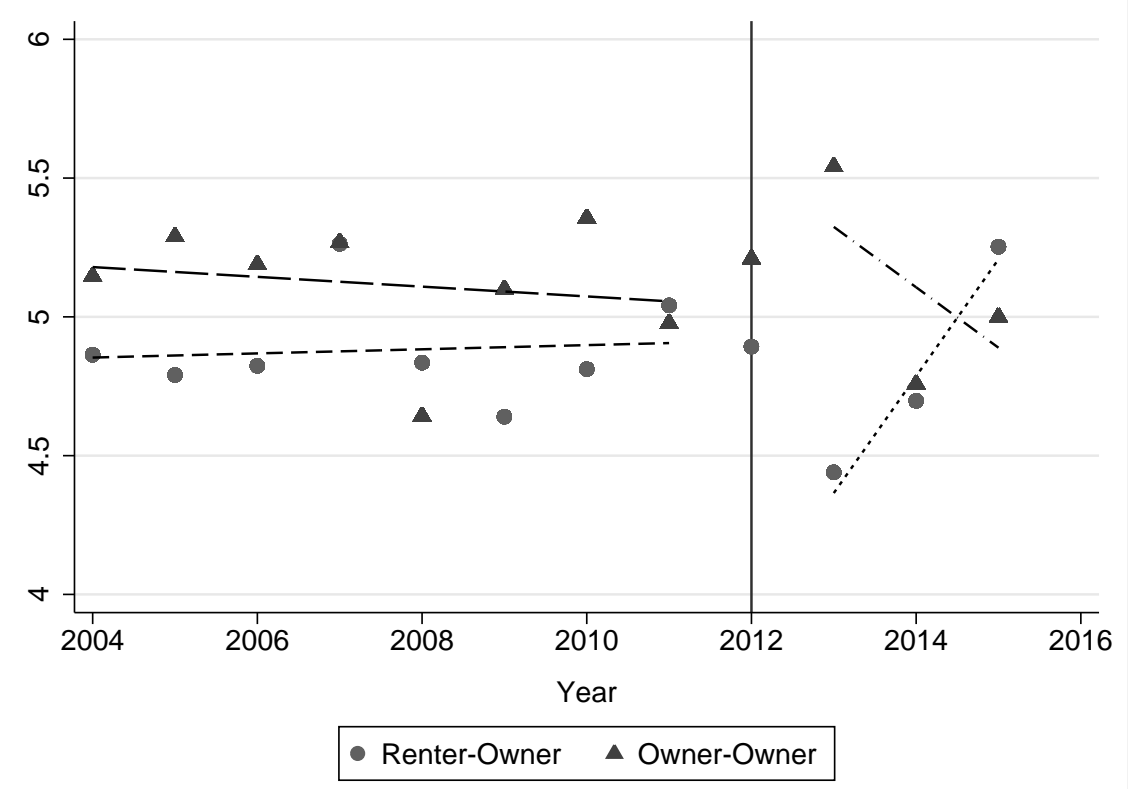

Note: Number of rooms in new home by year between 2004 and 2015. The vertical line depicts the reform date. Data stem from the Swiss Household Panel.

both single-family homes and condominiums. The net price paid per square meter, which we observe only for single-family homes, also rose significantly. The rise in paid net prices most likely reflects the overall increases in property prices over time. Given the observed downsizing in terms of the number of rooms of purchased property and the opposing increase in real estate prices at a national level, we can only draw conclusions on the net price effect. In all, we find no indication that affected individuals divert to lower priced real estate potentially also because of limited supply. In the absence of supply side information, it is impossible to infer the significance of a price channel. 


\section{Concluding remarks}

Home ownership has always played an important, if not the most important, role in individuals' asset portfolios and as an indirect means to provide for rainy days. In many countries, it functions as an additional pillar for old age security provisions. With the emergence of funded retirement savings plans, the trade-off between investing in a house or saving for old age in the second pillar has become more prevalent.

For policy makers, the question of how much individuals should be allowed to tap into second pillar assets to purchase a home arises. Early withdrawals can overcome liquidity constraints at younger ages and provide an alternative form of investment that potentially delivers a higher utility for pension plan beneficiaries. On the other hand, anticipated cash outs of retirement savings may account for inadequate means in retirement, especially in situations like macroeconomic crises or individual spells of bad luck such as divorce or healthcare costs.

Looking at Switzerland in particular, our paper provides an interesting case study for the link between home equity and retirement savings. Within the second pillar, which ranks among the world's largest funded pension schemes on a per capita basis, individuals are permitted to withdraw a large share of their accumulated retirement wealth for owner-occupied housing (the entire amount up to age 50). For reasons that lie outside the second pillar, the use of second pillar funds for down payments in real estate purchases was restricted in 2012. We use the policy change to analyze how individuals react to those changes in their decisions to cash-out pension savings for home purchases.

Our results show that the impact of the policy was noticeable. The share of individuals who withdrew in a given year dropped by one sixth. While the amount cashed out did not fall significantly on average, we observe a decline in the share of funds withdrawn, especially for individuals of older age and with lower levels of pension wealth. After the policy change, the share of individuals withdrawing their entire pension wealth (or the maximum amount allowed for those over age 50) fell. This finding suggests that after the reform relatively more individuals were constrained by factors outside the second pillar, most likely the hard equity requirement, than by available pension wealth. 
The more difficult question to answer is whether the new restrictions fundamentally threaten the goal to facilitate access to owner-occupied housing predominantly for middleincome households. While some potential buyers were driven out of the market, the overall evidence suggests that advance withdrawal rates are still relatively high and play an important role in overcoming liquidity constraints in home purchases. Although we cannot infer the welfare effects of the reform, it is clear that those who were most affected by the reform, older and lower-wealth households, were also the ones for whom purchasing residential property had been the riskiest even prior to the reform. 


\section{References}

Andrews, Dan and Aida Caldera Sánchez, "Drivers of Homeownership Rates in Selected OECD Countries," 2011. OECD Economics Department Working Papers No. 849, Paris: OECD Publishing.

Angelini, Viola, Agar Brugiavini, and Guglielmo Weber, "The Dynamics of Homeownership Among the 50+ in Europe," Journal of Population Economics, July 2014, 27 (3), 797-823.

Artle, Roland and Pravin Varaiya, "Life cycle consumption and homeownership," Journal of Economic Theory, 1978, 18 (1), 38-58.

Bourassa, Steven C., Donald R. Haurin, Patric H. Hendershott, and Martin Hoesli, "Determinants of the Homeownership Rate: An International Perspective," Journal of Housing Research, 2015, 24 (2), 193-210.

Brown, Jeffrey R., "Private pensions, mortality risk, and the decision to annuitize," Journal of Public Economics, 2001, 82, 29-62.

Bütler, Monika and Alma Ramsden, "Pricing annuities: The role of taxation in retirement decisions," February 2016b. mimeo, University of St. Gallen.

Chambers, Matthew, Carlos Garriga, and Don Schlagenhauf, "Accounting for Changes in the Homeownership Rate," International Economic Review, 2009, 50 (3), $677-726$.

Chiuri, Maria Concetta and Tullio Jappelli, "Financial market imperfections and home ownership: A comparative study," European Economic Review, 2003, 47, 857-875.

_ and _ , "Do the elderly reduce housing equity? An international comparison," Journal of Population Economics, 2010, 23 (2), 643-663.

Credit Suisse, "Residential Property in Switzerland: What Newcomers to Switzerland Need to Keep in Mind," Technical Report, Credit Suisse 2017. 
_, "Bewegung auf dem Hypothekarmarkt," Immobilienmonitor https://www.creditsuisse.com/ch/de/articles/private-banking/hypothekarschulden-in-der-schweiz-nehmenweniger-stark-zu-201806.html Q2 2018.

Davidoff, Thomas, Jeffrey R. Brown, and Peter A. Diamond, "Annuities and Individual Welfare," American Economic Review, 2005, 95 (5), 1573-1590.

Eurostat, "Distribution of population by tenure status, type of household and income group - EU-SILC survey," July 2019.

Federal Statistical Office, "Ausgewählte Indikatoren im regionalen Vergleich, 2019 (Kantone)," https://www.bfs.admin.ch/bfs/en/home/statistics/regional-statistics/regionalportraits-key-figures/cantons.assetdetail.7786542.html March 2019.

_ , "Household income and expenditure," https://www.bfs.admin.ch/bfs/en/home/statistics/ economic-social-situation-population/income-consumption-wealth/householdbudget.html November 2019.

Fehr, Hans and Maurice Hofmann, "Tenure Choice, Portfolio Structure and Long-term Care - Optimal Risk Management in Retirement," 2019. Presented at the Economics of Ageing Workshop 2019 at the University of New South Wales, Sydney, Australia on June 24, 2019.

Fernández-Villaverde, Jesús and Dirk Krueger, "Consumption over the Life Cycle: Facts from Consumer Expenditure Survey Data," Review of Economics and Statistics, 2007, $89(3), 552-565$.

FINMA, "Rundschreiben 2008/10 Selbstregulierung als Mindeststandard," November 2008.

_ , "Mortgage financing: FINMA recognises new minimum standards," June 2012.

_, "Mortgage financing: FINMA approves amended self-regulation," Press release July 2014.

_ , "Hypothekarmarkt im Fokus der FINMA-Aufsicht," PDF November 2016. Faktenblatt.

Firth, David, "Bias Reduction of Maximum Likelihood Estimates," Biometrika, 1993, 80 (1), 27-38. 
Fisher, Jonas D.M. and Martin Gervais, "Why has Home Ownership Fallen Among the Young?," International Economic Review, 2011, 52 (3), 883-912.

Foellmi, Reto and Isabel Z. Martínez, "Volatile Top Income Shares in Switzerland? Reassessing the Evolution between 1981 and 2010," Review of Economics and Statistics, 2017, 99 (5), 793-809.

Gyourko, Joseph and Peter Linneman, "The Changing Influences of Education, Income, Family Structure, and Race on Homeownership by Age over Time," Journal of Housing Research, 1997, 8 (1), 1-25.

Hilber, Christian A. L., "Why Are Homeownership Rates so Different across Europe?," 2007. Paper presented at the 14th Annual European Real Estate Society Conference, London.

King, Gary and Langche Zeng, "Logistic Regression in Rare Events Data," Political Analysis, 2001, 9 (2), 137-163.

Mitchell, Olivia S. and John Piggott, "Unlocking Housing Equity in Japan," Journal of the Japanese and International Economies, 2004, 18 (4), 466-505.

MoneyPark, "PK-Gelder für den Immobilienkauf: In Zukunft noch attraktiver?," https://moneypark.ch/news-wissen/immobilien/immobilien-kaufen/pk-gelder-furden-immobilienkauf-zukunft-noch-attraktiver/ November 2017.

NZZ, "Bitte Eigenkapital nachschiessen!," https://www.nzz.ch/finanzen/bitte-eigenkapitalnachschiessen-1.18219751 January 2014.

OECD, "OECD Economic Survey: Switzerland," Technical Report, OECD November 2019.

Painter, Gary and KwanOk Lee, "Housing Tenure Transitions of Older Households: Life cycle, demographic, and familial factors," Regional Science and Urban Economics, November 2009, 39 (6), 749-760.

Schmidheiny, Kurt, "Emerging Lessons from Half a Century of Fiscal Federalism in Switzerland," Swiss Journal of Economics and Statistics, 2017, II (1), 73-101. 
Seiler Zimmermann, Yvonne, "Nutzung von Vorsorgegeldern zur Finanzierung von selbstgenutztem Wohneigentum," Verlag IFZ - Hochschule Luzern 2015.

Sinai, Todd and Nicholas S. Souleles, "Owner-Occupied Housing as a Hedge Against Rent Risk," The Quarterly Journal of Economics, 2005, 120 (1), 763-789.

Swiss Bankers Association, "Richtlinien betreffend Mindestanforderungen bei Hypothekarfinanzierungen," http://www.swissbanking.org/de/services/bibliothek/richtlinien Basel July 2014.

Swiss National Bank, "Inlandkredite (Benützung) nach Branchen und Fälligkeit," https://data.snb.ch/de/topics/banken\#!/cube/bakredsekbrlzm?fromDate=200901\&toDate=2018-03\&dimSel=D1(H),D2(F,C1,C0,C2,C3,C4,C5,C6),D3(T1,AA,C,K) March 2018.

_. "Swiss Financial Accounts, 2017 edition," Technical Report, Swiss National Bank November 2018 .

Swiss Real Estate Datapool (SRED), "SRED NEWSLETTER Q1 2014," Technical Report, SRED 2014.

Turner, Tracy and Marc T. Smith, "Exits from Homeownership: The Effects of Race, Ethnicity, and Income," Journal of Regional Science, 2009, 49 (1), 1-32.

Venti, Steven F. and David A. Wise, "Aging and Housing Equity: Another Look," in David A. Wise, ed., Perspectives on the Economics of Aging, University of Chicago Press, 2004, pp. 9-48.

Wüest Partner, "Property Market Switzerland 2014 Q1," Technical Report, Wüest Partner 2014. 2014 Q1.

_ , "Property Market Switzerland 2019 Q3," Technical Report, Wüest Partner 2019. 2019 Q3.

Yaari, Menahem E., "Uncertain Lifetime, Life Insurance, and the Theory of the Consumer," Review of Economic Studies, 1965, 32 (2), 137-150. 
Yang, Fang, "Consumption over the life cycle: How different is housing?," Review of Economic Dynamics, 2009, 12, 423-443.

Yogo, Motohiro, "Portfolio choice in retirement: Health risk and the demand for annuities, housing, and risky assets," Journal of Monetary Economics, June 2016, 80, 17-34. 
A Data description 


\section{Table 9: DATA DEscription AND SOURCES}

\begin{tabular}{|c|c|c|}
\hline Name & Description & Source \\
\hline Age & $\begin{array}{l}\text { Difference between year of observation and birth } \\
\text { year of insured person in } 5 \text {-year bins. }\end{array}$ & Pension provider \\
\hline Condominium & $\begin{array}{l}\text { Annual small-scale transaction price index for a } \\
\text { condominium by MS-region. Reflects prices of a } \\
\text { medium-sized property with average amenities. }\end{array}$ & Wüst \& Partner \\
\hline Female & $\begin{array}{l}\text { A binary indicator equal to one if the insured per- } \\
\text { son's gender is female. }\end{array}$ & Pension provider \\
\hline Income in CHF 1,000 & $\begin{array}{l}\text { The insured person's annual wage in units of CHF } \\
1,000 \text {. }\end{array}$ & Pension provider \\
\hline Interest rate & Monthly rate in Switzerland. & Swiss National Bank \\
\hline Married & $\begin{array}{l}\text { A binary indicator equal to one if the insured per- } \\
\text { son's marital status is married. }\end{array}$ & Pension provider \\
\hline Not eligible & $\begin{array}{l}\text { A binary indicator equal to one if the insured person } \\
\text { is not eligible to withdraw pension assets in advance } \\
\text { for home ownership because the minimum duration } \\
\text { period of } 5 \text { years between withdrawals has not yet } \\
\text { passed. }\end{array}$ & \\
\hline $\begin{array}{l}\text { Pension assets in } \\
1,000\end{array}$ & $\begin{array}{l}\text { The insured person's pension assets in units of CHF } \\
1,000 \text {. }\end{array}$ & Pension provider \\
\hline Reform & $\begin{array}{l}\text { A binary indicator equal to one if the insured person } \\
\text { is observed post-reform (2013). }\end{array}$ & \\
\hline Single-family house & $\begin{array}{l}\text { Annual small-scale transaction price index for a } \\
\text { single-family house by MS-region. Reflects prices } \\
\text { of a medium-sized property with average amenities. }\end{array}$ & Wüst \& Partner \\
\hline Tax level & $\begin{array}{l}\text { A level indicator of the insured person's cantonal } \\
\text { tax rate. Level } 1 \text { corresponds to a low cantonal } \\
\text { tax rate and includes the cantons of Zug, Geneva, } \\
\text { Ticino, Schwyz and Zurich. Level } 2 \text { corresponds } \\
\text { to a medium cantonal tax rate and includes the } \\
\text { cantons of Aargau, Thurgau, Baselland, Basel- } \\
\text { Stadt, Fribourg, St.Gallen, Uri, Obwalden, Lucerne, } \\
\text { Schaffhausen, Appenzell-Innerrhoden, Graubuen- } \\
\text { den, Valais and Nidwalden. Level } 3 \text { corresponds } \\
\text { to a high cantonal tax rate and includes the can- } \\
\text { tons of Neuchatel, Jura, Solothurn, Appenzell- } \\
\text { Ausserrhoden and Berne. }\end{array}$ & Federal Tax Administration \\
\hline Income tax rate & Tax rate on income based on municipality. & Federal Tax Administration \\
\hline Capital tax rate & Tax rate on capital payouts based on municipality. & Federal Tax Administration \\
\hline Urban & $\begin{array}{l}\text { A level indicator of the insured person's degree of } \\
\text { urbanity based on the home municipality. Level } 1 \\
\text { corresponds to a central municipality. Level } 2 \text { cor- } \\
\text { responds to an agglomeration. Level } 3 \text { corresponds } \\
\text { to an isolated town. Level } 4 \text { corresponds to a rural } \\
\text { area. }\end{array}$ & Federal Statistical Office \\
\hline Withdrawal dummy & $\begin{array}{l}\text { A binary indicator equal to one if the insured person } \\
\text { has withdrawn pension assets in advance for home } \\
\text { ownership. }\end{array}$ & Pension provider \\
\hline Withdrawal share & $\begin{array}{l}\text { Amount of pension assets withdrawn for home own- } \\
\text { ership relative to total pension wealth. }\end{array}$ & \\
\hline
\end{tabular}

Note: Name, description and source information by variable. 
B Tables and Figures 
Table 10: Extensive MARgin Robust to PERSONs AGED $\leq 55 \mathrm{Y}$.

\begin{tabular}{|c|c|c|c|c|}
\hline VARIABLES & $\begin{array}{c}\text { (1) } \\
\text { Raw }\end{array}$ & $\begin{array}{c}(2) \\
\text { Individual } \\
\text { controls }\end{array}$ & $\begin{array}{c}(3) \\
\text { Individual } \\
\text { controls }\end{array}$ & $\begin{array}{c}\text { (4) } \\
\text { Baseline }\end{array}$ \\
\hline Reform & $\begin{array}{c}-0.0013^{*} \\
(0.0007)\end{array}$ & $\begin{array}{c}-0.0012^{*} \\
(0.0007)\end{array}$ & $\begin{array}{c}-0.0019^{* *} \\
(0.0008)\end{array}$ & $\begin{array}{c}-0.0014^{*} \\
(0.0008)\end{array}$ \\
\hline Age: $25-29 y$. & & $\begin{array}{c}-0.0017 \\
(0.0014)\end{array}$ & $\begin{array}{l}-0.0014 \\
(0.0015)\end{array}$ & $\begin{array}{l}-0.0014 \\
(0.0015)\end{array}$ \\
\hline Age: $30-34 y$. & & $\begin{array}{c}0.0035^{* * *} \\
(0.0013)\end{array}$ & $\begin{array}{c}0.0034^{* *} \\
(0.0013)\end{array}$ & $\begin{array}{c}0.0036^{* * *} \\
(0.0013)\end{array}$ \\
\hline Age: $35-39 y$. & & $\begin{array}{c}0.0076^{* * *} \\
(0.0014)\end{array}$ & $\begin{array}{c}0.0076^{* * *} \\
(0.0015)\end{array}$ & $\begin{array}{c}0.0078^{* * *} \\
(0.0015)\end{array}$ \\
\hline Age: $40-44 y$. & & $\begin{array}{c}0.0045^{* * *} \\
(0.0011)\end{array}$ & $\begin{array}{c}0.0039^{* * *} \\
(0.0012)\end{array}$ & $\begin{array}{c}0.0041^{* * *} \\
(0.0012)\end{array}$ \\
\hline Age: $45-49 y$. & & $\begin{array}{c}0.0039 * * * \\
(0.0010)\end{array}$ & $\begin{array}{c}0.0042^{* * *} \\
(0.0011)\end{array}$ & $\begin{array}{c}0.0042^{* * * *} \\
(0.0011)\end{array}$ \\
\hline Female & & $\begin{array}{c}-0.0024^{* * *} \\
(0.0008)\end{array}$ & $\begin{array}{c}-0.0028^{* * *} \\
(0.0009)\end{array}$ & $\begin{array}{c}-0.0025^{* * *} \\
(0.0009)\end{array}$ \\
\hline Married & & $\begin{array}{c}0.0029^{* * *} \\
(0.0008)\end{array}$ & $\begin{array}{c}0.0033^{* * *} \\
(0.0008)\end{array}$ & $\begin{array}{c}0.0032^{* * *} \\
(0.0008)\end{array}$ \\
\hline Income in $\mathrm{CHF} 10,000$ & & $\begin{array}{c}0.0000 \\
(0.0002)\end{array}$ & $\begin{array}{c}0.0001 \\
(0.0002)\end{array}$ & $\begin{array}{c}0.0002 \\
(0.0002)\end{array}$ \\
\hline Pension assets in CHF 100,000 & & $\begin{array}{c}-0.0002 \\
(0.0003)\end{array}$ & $\begin{array}{c}-0.0004 \\
(0.0004)\end{array}$ & $\begin{array}{c}-0.0003 \\
(0.0004)\end{array}$ \\
\hline Condominium & & & & $\begin{array}{c}0.0001^{* *} \\
(0.0000)\end{array}$ \\
\hline Single-family house & & & & $\begin{array}{c}-0.0001^{* * *} \\
(0.0000)\end{array}$ \\
\hline Income tax rate & & & & $\begin{array}{c}-0.0004 \\
(0.0084)\end{array}$ \\
\hline Capital tax rate & & & & $\begin{array}{c}-0.0249 \\
(0.0318)\end{array}$ \\
\hline Urban & & & & $\begin{array}{c}0.0011^{* *} \\
(0.0004)\end{array}$ \\
\hline Constant & $\begin{array}{c}0.0084^{* * *} \\
(0.0005)\end{array}$ & $\begin{array}{c}0.0043^{* * *} \\
(0.0015)\end{array}$ & $\begin{array}{c}0.0043^{* * *} \\
(0.0015)\end{array}$ & $\begin{array}{c}0.0098^{* * *} \\
(0.0035)\end{array}$ \\
\hline Observations & 55,779 & 55,779 & 49,929 & 49,929 \\
\hline Adjusted R-squared & 0.0000 & 0.0013 & 0.0016 & 0.0022 \\
\hline
\end{tabular}

Note: ${ }^{* * *} \mathrm{p}<0.01,{ }^{* *} \mathrm{p}<0.05,{ }^{*} \mathrm{p}<0.1$. OLS regressions. The dependent variable is the probability to withdraw pension assets in advance. Standard errors are clustered at the individual level. Columns (1)-(4) are based on an unbalanced sample including those who are observed only in either 2011 or 2013. Column (1) presents a "raw" regression. In column (2) we control for individual covariates. In column (3) we additionally condition on non-missing regional covariates. Column (4) presents the baseline, where we control for individual and regional covariates. The sample is restricted to individuals aged $\leq 55$ years. The reference age group is $\geq 50$ years. The capital tax rate is conditional on the withdrawal amount. For non-withdrawers, it is calculated based on an assumed withdrawal of the mean share of $67 \%$ of pension wealth in advance. 
Table 11: Intensive Margin SEnsitive to Persons AGed $\leq 55$ Y.

\begin{tabular}{|c|c|c|c|c|}
\hline VARIABLES & $\begin{array}{r}\text { (1) } \\
\text { Raw } \\
\end{array}$ & $\begin{array}{c}(2) \\
\text { Individual } \\
\text { controls }\end{array}$ & $\begin{array}{c}(3) \\
\text { Individual } \\
\text { controls }\end{array}$ & $\begin{array}{c}\text { (4) } \\
\text { Baseline }\end{array}$ \\
\hline Reform & $\begin{array}{c}-0.0328 \\
(0.0252)\end{array}$ & $\begin{array}{c}-0.0379^{*} \\
(0.0225)\end{array}$ & $\begin{array}{l}-0.0203 \\
(0.0244)\end{array}$ & $\begin{array}{c}-0.0308 \\
(0.0253)\end{array}$ \\
\hline Age: $25-29 y$. & & $\begin{array}{c}0.2323^{* * *} \\
(0.0601)\end{array}$ & $\begin{array}{c}0.2167^{* * *} \\
(0.0639)\end{array}$ & $\begin{array}{c}0.2208^{* * *} \\
(0.0660)\end{array}$ \\
\hline Age: $30-34 y$. & & $\begin{array}{c}0.2204^{* * *} \\
(0.0504)\end{array}$ & $\begin{array}{c}0.2001^{* * *} \\
(0.0544)\end{array}$ & $\begin{array}{c}0.2196^{* * *} \\
(0.0547)\end{array}$ \\
\hline Age: $35-39 y$. & & $\begin{array}{c}0.1682^{* * *} \\
(0.0479)\end{array}$ & $\begin{array}{c}0.1650^{* * *} \\
(0.0503)\end{array}$ & $\begin{array}{c}0.1754^{* * *} \\
(0.0496)\end{array}$ \\
\hline Age: $40-44 y$. & & $\begin{array}{c}0.1196^{* * *} \\
(0.0460)\end{array}$ & $\begin{array}{l}0.0866^{*} \\
(0.0494)\end{array}$ & $\begin{array}{c}0.1013^{* *} \\
(0.0491)\end{array}$ \\
\hline Age: $45-49 y$. & & $\begin{array}{c}0.0907^{* *} \\
(0.0434)\end{array}$ & $\begin{array}{c}0.0914^{* *} \\
(0.0461)\end{array}$ & $\begin{array}{c}0.0913^{* *} \\
(0.0443)\end{array}$ \\
\hline Female & & $\begin{array}{c}0.0377 \\
(0.0243)\end{array}$ & $\begin{array}{c}0.0392 \\
(0.0258)\end{array}$ & $\begin{array}{c}0.0285 \\
(0.0266)\end{array}$ \\
\hline Married & & $\begin{array}{c}0.0080 \\
(0.0247)\end{array}$ & $\begin{array}{c}0.0167 \\
(0.0274)\end{array}$ & $\begin{array}{c}-0.0019 \\
(0.0319)\end{array}$ \\
\hline Income in CHF 10,000 & & $\begin{array}{c}0.0019 \\
(0.0059)\end{array}$ & $\begin{array}{l}-0.0006 \\
(0.0062)\end{array}$ & $\begin{array}{c}0.0002 \\
(0.0065)\end{array}$ \\
\hline Pension assets in CHF 100,000 & & $\begin{array}{c}-0.0900 * * * \\
(0.0238)\end{array}$ & $\begin{array}{c}-0.0862^{* * *} \\
(0.0264)\end{array}$ & $\begin{array}{c}-0.0907^{* * *} \\
(0.0284)\end{array}$ \\
\hline Condominium & & & & $\begin{array}{c}-0.0006 \\
(0.0009)\end{array}$ \\
\hline Single-family house & & & & $\begin{array}{c}0.0018 \\
(0.0012)\end{array}$ \\
\hline Income tax rate & & & & $\begin{array}{l}-0.4678 \\
(0.2978)\end{array}$ \\
\hline Capital tax rate & & & & $\begin{array}{c}2.6908^{* * *} \\
(1.0125)\end{array}$ \\
\hline Urban & & & & $\begin{array}{l}-0.0002 \\
(0.0105)\end{array}$ \\
\hline Constant & $\begin{array}{c}0.6982^{* * *} \\
(0.0164)\end{array}$ & $\begin{array}{c}0.6492^{* * * *} \\
(0.0570)\end{array}$ & $\begin{array}{c}0.6604^{* * *} \\
(0.0615)\end{array}$ & $\begin{array}{c}0.4563^{* * *} \\
(0.0908)\end{array}$ \\
\hline Observations & 430 & 430 & 373 & 373 \\
\hline Adjusted R-squared & 0.0017 & 0.2742 & 0.2607 & 0.2885 \\
\hline
\end{tabular}

Note: $* * * \mathrm{p}<0.01,{ }^{*} \mathrm{p}<0.05,{ }^{*} \mathrm{p}<0.1$. OLS regressions. The dependent variable is the share of pension assets claimed as advance withdrawal. Standard errors are clustered at the individual level.Columns (1)-(4) are based on an unbalanced sample of withdrawers in 2011 and 2013. Column (1) presents a "raw" regression. In column (2) we control for individual covariates. In column (3) we additionally condition on non-missing regional covariates. Column (4) presents the baseline, where we control for individual and regional covariates. The sample is restricted to individuals aged $\leq 55$ years. The reference age group is $\geq 50$ years. 
Table 12: MAIN RESUlts ROBUST TO PROBIT SPECIFICATION

\begin{tabular}{|c|c|c|c|c|}
\hline VARIABLES & $\begin{array}{l}\text { (1) } \\
\text { Raw }\end{array}$ & $\begin{array}{c}(2) \\
\text { Individual } \\
\text { controls }\end{array}$ & $\begin{array}{c}\text { (3) } \\
\text { Individual } \\
\text { controls }\end{array}$ & $\begin{array}{c}\text { (4) } \\
\text { Baseline }\end{array}$ \\
\hline Reform & $\begin{array}{c}-0.0013^{* *} \\
(0.0006)\end{array}$ & $\begin{array}{l}-0.0012^{*} \\
(0.0006)\end{array}$ & $\begin{array}{c}-0.0018 * * * \\
(0.0007)\end{array}$ & $\begin{array}{l}-0.0013^{*} \\
(0.0007)\end{array}$ \\
\hline Age: $25-29 y$. & & $\begin{array}{c}0.0068 \\
(0.0043)\end{array}$ & $\begin{array}{c}0.0064 \\
(0.0043)\end{array}$ & $\begin{array}{c}0.0062 \\
(0.0043)\end{array}$ \\
\hline Age: $30-34 y$. & & $\begin{array}{c}0.0146 \text { *** } \\
(0.0032)\end{array}$ & $\begin{array}{c}0.0133^{* * *} \\
(0.0032)\end{array}$ & $\begin{array}{c}0.0130 * * * \\
(0.0032)\end{array}$ \\
\hline Age: $35-39 y$. & & $\begin{array}{c}0.0173^{* * *} \\
(0.0032)\end{array}$ & $\begin{array}{c}0.0159 * * * \\
(0.0032)\end{array}$ & $\begin{array}{c}0.0159 * * * \\
(0.0032)\end{array}$ \\
\hline Age: $40-44 y$. & & $\begin{array}{c}0.0150 * * * \\
(0.0031)\end{array}$ & $\begin{array}{c}0.0132^{* * *} \\
(0.0031)\end{array}$ & $\begin{array}{c}0.0132^{* * *} \\
(0.0031)\end{array}$ \\
\hline Age: $45-49 y$. & & $\begin{array}{c}0.0144^{* * *} \\
(0.0031)\end{array}$ & $\begin{array}{c}0.0132^{* * *} \\
(0.0031)\end{array}$ & $\begin{array}{c}0.0132^{* * *} \\
(0.0030)\end{array}$ \\
\hline Age: $50-54 y$. & & $\begin{array}{c}0.0103^{* * *} \\
(0.0030)\end{array}$ & $\begin{array}{c}0.0087^{* * *} \\
(0.0030)\end{array}$ & $\begin{array}{c}0.0088^{* * *} \\
(0.0030)\end{array}$ \\
\hline Age: $55-59 y$. & & $\begin{array}{c}0.0081^{* * *} \\
(0.0030)\end{array}$ & $\begin{array}{c}0.0066^{* *} \\
(0.0030)\end{array}$ & $\begin{array}{c}0.0066^{* *} \\
(0.0030)\end{array}$ \\
\hline Female & & $\begin{array}{c}-0.0021^{* * *} \\
(0.0007)\end{array}$ & $\begin{array}{c}-0.0024^{* * *} \\
(0.0008)\end{array}$ & $\begin{array}{c}-0.0023^{* * *} \\
(0.0008)\end{array}$ \\
\hline Married & & $\begin{array}{c}0.0027^{* * *} \\
(0.0007)\end{array}$ & $\begin{array}{c}0.0031^{* * *} \\
(0.0008)\end{array}$ & $\begin{array}{c}0.0029 * * * \\
(0.0008)\end{array}$ \\
\hline Income in $\mathrm{CHF} 10,000$ & & $\begin{array}{l}-0.0001 \\
(0.0001)\end{array}$ & $\begin{array}{l}-0.0000 \\
(0.0002)\end{array}$ & $\begin{array}{c}0.0000 \\
(0.0002)\end{array}$ \\
\hline Pension assets in CHF 100,000 & & $\begin{array}{c}0.0004 \\
(0.0003)\end{array}$ & $\begin{array}{c}0.0003 \\
(0.0003)\end{array}$ & $\begin{array}{c}0.0005 \\
(0.0003)\end{array}$ \\
\hline Condominium & & & & $\begin{array}{l}0.0000^{*} \\
(0.0000)\end{array}$ \\
\hline Single-family house & & & & $\begin{array}{c}-0.0001^{* * *} \\
(0.0000)\end{array}$ \\
\hline Income tax rate & & & & $\begin{array}{c}0.0000 \\
(0.0074)\end{array}$ \\
\hline Capital tax rate & & & & $\begin{array}{c}-0.0715^{* *} \\
(0.0294)\end{array}$ \\
\hline Urban & & & & $\begin{array}{c}0.0009 * * * \\
(0.0003)\end{array}$ \\
\hline Observations & 67,503 & 67,503 & 60,320 & 60,320 \\
\hline
\end{tabular}

Note: $* * * \mathrm{p}<0.01, * * \mathrm{p}<0.05, * \mathrm{p}<0.1$. Probit regressions. The dependent variable is the probability to withdraw pension assets in advance. Standard errors are clustered at the individual level. Columns (1)-(4) are based on an unbalanced sample including those who are observed only in either 2011 or 2013. Column (1) presents a "raw" regression. In column (2) we control for individual covariates. In column (3) we additionally condition on non-missing regional covariates. Column (4) presents the baseline, where we control for individual and regional covariates. The reference age group is $\geq 60$ years. The capital tax rate is conditional on the withdrawal amount. For non-withdrawers, it is calculated based on an assumed withdrawal of the mean share of $67 \%$ of pension wealth in advance. 
Table 13: MAin Results Robust to LOGIT SPECIFICATION

\begin{tabular}{|c|c|c|c|c|}
\hline VARIABLES & $\begin{array}{c}(1) \\
\text { Raw }\end{array}$ & $\begin{array}{c}(2) \\
\text { Individual } \\
\text { controls }\end{array}$ & $\begin{array}{c}(3) \\
\text { Individual } \\
\text { controls }\end{array}$ & $\begin{array}{c}\text { (4) } \\
\text { Baseline }\end{array}$ \\
\hline Reform & $\begin{array}{c}-0.0013^{* *} \\
(0.0006)\end{array}$ & $\begin{array}{r}-0.0012^{*} \\
(0.0006)\end{array}$ & $\begin{array}{c}-0.0018^{* * *} \\
(0.0007)\end{array}$ & $\begin{array}{c}-0.0013^{*} \\
(0.0007)\end{array}$ \\
\hline Age: $25-29 y$. & & $\begin{array}{c}0.0077 \\
(0.0051)\end{array}$ & $\begin{array}{c}0.0072 \\
(0.0050)\end{array}$ & $\begin{array}{c}0.0068 \\
(0.0049)\end{array}$ \\
\hline Age: $30-34 y$. & & $\begin{array}{c}0.0161^{* * *} \\
(0.0038)\end{array}$ & $\begin{array}{c}0.0145^{* * *} \\
(0.0038)\end{array}$ & $\begin{array}{c}0.0142^{* * *} \\
(0.0038)\end{array}$ \\
\hline Age: $35-39 y$. & & $\begin{array}{c}0.0188 * * * \\
(0.0038)\end{array}$ & $\begin{array}{c}0.0171^{* * *} \\
(0.0037)\end{array}$ & $\begin{array}{c}0.0171^{* * *} \\
(0.0037)\end{array}$ \\
\hline Age: $40-44 y$. & & $\begin{array}{c}0.0165^{* * *} \\
(0.0037)\end{array}$ & $\begin{array}{c}0.0145^{* * *} \\
(0.0037)\end{array}$ & $\begin{array}{c}0.0143^{* * * *} \\
(0.0037)\end{array}$ \\
\hline Age: $45-49 y$. & & $\begin{array}{c}0.0158 * * * \\
(0.0037)\end{array}$ & $\begin{array}{c}0.0144^{* * *} \\
(0.0036)\end{array}$ & $\begin{array}{c}0.0143^{* * *} \\
(0.0036)\end{array}$ \\
\hline Age: $50-54 y$. & & $\begin{array}{c}0.0116^{* * *} \\
(0.0036)\end{array}$ & $\begin{array}{c}0.0098 * * * \\
(0.0036)\end{array}$ & $\begin{array}{c}0.0098 * * * \\
(0.0036)\end{array}$ \\
\hline Age: $55-59 y$. & & $\begin{array}{c}0.0093 * * \\
(0.0037)\end{array}$ & $\begin{array}{c}0.0075 * * \\
(0.0036)\end{array}$ & $\begin{array}{c}0.0075 * * \\
(0.0036)\end{array}$ \\
\hline Female & & $\begin{array}{c}-0.0022^{* * *} \\
(0.0007)\end{array}$ & $\begin{array}{c}-0.0025^{* * *} \\
(0.0008)\end{array}$ & $\begin{array}{c}-0.0024^{* * *} \\
(0.0008)\end{array}$ \\
\hline Married & & $\begin{array}{c}0.0028 * * * \\
(0.0007)\end{array}$ & $\begin{array}{c}0.0032^{* * *} \\
(0.0008)\end{array}$ & $\begin{array}{c}0.0031^{* * *} \\
(0.0008)\end{array}$ \\
\hline Income in $\mathrm{CHF} 10,000$ & & $\begin{array}{l}-0.0001 \\
(0.0001)\end{array}$ & $\begin{array}{l}-0.0000 \\
(0.0002)\end{array}$ & $\begin{array}{c}0.0000 \\
(0.0002)\end{array}$ \\
\hline Pension assets in CHF 100,000 & & $\begin{array}{c}0.0004 \\
(0.0003)\end{array}$ & $\begin{array}{c}0.0003 \\
(0.0003)\end{array}$ & $\begin{array}{c}0.0005 \\
(0.0003)\end{array}$ \\
\hline Condominium & & & & $\begin{array}{l}0.0000^{*} \\
(0.0000)\end{array}$ \\
\hline Single-family house & & & & $\begin{array}{c}-0.0001^{* * *} \\
(0.0000)\end{array}$ \\
\hline Income tax rate & & & & $\begin{array}{c}0.0001 \\
(0.0073)\end{array}$ \\
\hline Capital tax rate & & & & $\begin{array}{c}-0.0734^{* *} \\
(0.0304)\end{array}$ \\
\hline Urban & & & & $\begin{array}{r}0.0008^{* *} \\
(0.0003)\end{array}$ \\
\hline Observations & 67,503 & 67,503 & 60,320 & 60,320 \\
\hline
\end{tabular}

Note: ${ }^{* * *} \mathrm{p}<0.01,{ }^{*} * \mathrm{p}<0.05,{ }^{*} \mathrm{p}<0.1$. Logit regressions. The dependent variable is the probability to withdraw pension assets in advance. Standard errors are clustered at the individual level. Columns (1)-(4) are based on an unbalanced sample including those who are observed only in either 2011 or 2013. Column (1) presents a "raw" regression. In column (2) we control for individual covariates. In column (3) we additionally condition on non-missing regional covariates. Column (4) presents the baseline, where we control for individual and regional covariates. The reference age group is $\geq 60$ years. The capital tax rate is conditional on the withdrawal amount. For non-withdrawers, it is calculated based on an assumed withdrawal of the mean share of $67 \%$ of pension wealth in advance. 
Table 14: Main Results Robust to Firth LOGistic REgression

\begin{tabular}{|c|c|c|c|c|}
\hline VARIABLES & $\begin{array}{l}\text { (1) } \\
\text { Raw } \\
\end{array}$ & $\begin{array}{c}(2) \\
\text { Individual } \\
\text { controls }\end{array}$ & $\begin{array}{c}(3) \\
\text { Individual } \\
\text { controls }\end{array}$ & $\begin{array}{c}\text { (4) } \\
\text { Baseline }\end{array}$ \\
\hline Reform & $\begin{array}{c}-0.0013^{* *} \\
(0.0006)\end{array}$ & $\begin{array}{c}-0.0012^{*} \\
(0.0006)\end{array}$ & $\begin{array}{c}-0.0018^{* * *} \\
(0.0007)\end{array}$ & $\begin{array}{c}-0.0013^{*} \\
(0.0007)\end{array}$ \\
\hline Age: $25-29 y$. & & $\begin{array}{c}0.0079 \\
(0.0048)\end{array}$ & $\begin{array}{c}0.0074 \\
(0.0047)\end{array}$ & $\begin{array}{c}0.0068 \\
(0.0049)\end{array}$ \\
\hline Age: $30-34 y$. & & $\begin{array}{c}0.0156^{* * *} \\
(0.0036)\end{array}$ & $\begin{array}{c}0.0140^{* * *} \\
(0.0036)\end{array}$ & $\begin{array}{c}0.0142^{* * *} \\
(0.0037)\end{array}$ \\
\hline Age: $35-39 y$. & & $\begin{array}{c}0.0183^{* * *} * \\
(0.0036)\end{array}$ & $\begin{array}{c}0.0167 * * * \\
(0.0035)\end{array}$ & $\begin{array}{c}0.0171^{* * *} \\
(0.0037)\end{array}$ \\
\hline Age: $40-44 y$. & & $\begin{array}{c}0.0159^{* * *} * \\
(0.0036)\end{array}$ & $\begin{array}{c}0.0140^{* * *} \\
(0.0035)\end{array}$ & $\begin{array}{c}0.0143^{* * *} \\
(0.0036)\end{array}$ \\
\hline Age: $45-49 y$. & & $\begin{array}{c}0.0152^{* * *} \\
(0.0035)\end{array}$ & $\begin{array}{c}0.0139^{* * *} \\
(0.0034)\end{array}$ & $\begin{array}{c}0.0143^{* * *} \\
(0.0036)\end{array}$ \\
\hline Age: $50-54 y$. & & $\begin{array}{c}0.0110^{* * *} \\
(0.0035)\end{array}$ & $\begin{array}{c}0.0093^{* * *} \\
(0.0034)\end{array}$ & $\begin{array}{c}0.0098^{* * *} \\
(0.0035)\end{array}$ \\
\hline Age: $55-59 y$. & & $\begin{array}{c}0.0086^{* *} \\
(0.0035)\end{array}$ & $\begin{array}{c}0.0070^{* *} \\
(0.0034)\end{array}$ & $\begin{array}{c}0.0075^{* *} \\
(0.0036)\end{array}$ \\
\hline Female & & $\begin{array}{c}-0.0022^{* * *} \\
(0.0007)\end{array}$ & $\begin{array}{c}-0.0025^{* * *} \\
(0.0008)\end{array}$ & $\begin{array}{c}-0.0024^{* * *} \\
(0.0008)\end{array}$ \\
\hline Married & & $\begin{array}{c}0.0028^{* * *} \\
(0.0007)\end{array}$ & $\begin{array}{c}0.0032^{* * *} \\
(0.0008)\end{array}$ & $\begin{array}{c}0.0031^{* * *} \\
(0.0009)\end{array}$ \\
\hline Income in CHF 10,000 & & $\begin{array}{c}-0.0001 \\
(0.0002)\end{array}$ & $\begin{array}{c}-0.0000 \\
(0.0002)\end{array}$ & $\begin{array}{c}0.0000 \\
(0.0002)\end{array}$ \\
\hline Pension assets in CHF 100,000 & & $\begin{array}{c}0.0004 \\
(0.0003)\end{array}$ & $\begin{array}{c}0.0004 \\
(0.0003)\end{array}$ & $\begin{array}{c}0.0005 \\
(0.0003)\end{array}$ \\
\hline Condominium & & & & $\begin{array}{l}0.0000^{*} \\
(0.0000)\end{array}$ \\
\hline Single-family house & & & & $\begin{array}{c}-0.0001^{* * *} \\
(0.0000)\end{array}$ \\
\hline Income tax rate & & & & $\begin{array}{c}0.0001 \\
(0.0083)\end{array}$ \\
\hline Capital tax rate & & & & $\begin{array}{c}-0.0734^{* * *} \\
(0.0277)\end{array}$ \\
\hline Urban & & & & $\begin{array}{c}0.0008^{* * *} \\
(0.0003)\end{array}$ \\
\hline Observations & 67,503 & 67,503 & 60,320 & 60,320 \\
\hline
\end{tabular}

Note: ${ }^{* * *} \mathrm{p}<0.01,{ }^{*} * \mathrm{p}<0.05,{ }^{*} \mathrm{p}<0.1$. Firth logistic penalized maximum likelihood regression. The dependent variable is the probability to withdraw pension assets in advance. Columns (1)-(4) are based on an unbalanced sample including those who are observed only in either 2011 or 2013. Column (1) presents a "raw" regression. In column (2) we control for individual covariates. In column (3) we additionally condition on non-missing regional covariates. Column (4) presents the baseline, where we control for individual and regional covariates. The reference age group is $\geq 60$ years. The capital tax rate is conditional on the withdrawal amount. For non-withdrawers, it is calculated based on an assumed withdrawal of the mean share of $67 \%$ of pension wealth in advance. 
Table 15: Descriptive statistics By YeAR of REAL ESTAte PURChase

\begin{tabular}{|c|c|c|c|c|c|}
\hline & 2011 & 2013 & Diff. & SE & p-value \\
\hline \multicolumn{6}{|l|}{$\overline{\operatorname{Total}(N=13,552)}$} \\
\hline No. transactions & 6,832 & 6,720 & -112 & & \\
\hline \multicolumn{6}{|c|}{ Single-family home $(N=4,528)$} \\
\hline No. transactions & 2,415 & 2,113 & -305 & & \\
\hline Net price $(1,000 \mathrm{CHF})$ & $1,124.60$ & $1,219.67$ & 95.07 & 27.82 & 0.001 \\
\hline Net price sqm. (CHF) & $2,287.31$ & $2,483.32$ & 196.008 & 45.550 & 0.000 \\
\hline Age & 44.61 & 44.29 & -0.319 & 0.892 & 0.721 \\
\hline Female & 0.25 & 0.25 & 0.000 & 0.013 & 0.973 \\
\hline Swiss & 0.83 & 0.84 & 0.011 & 0.011 & 0.330 \\
\hline \multicolumn{6}{|l|}{$\overline{\text { Condominium }(N=9,024)}$} \\
\hline No. transactions & 4,417 & 4,607 & 181 & & \\
\hline Net price $(\mathrm{CHF})$ & $875,446.12$ & $983,507.50$ & $108,061.38$ & 12985.99 & 0.000 \\
\hline Age & 50.75 & 49.91 & -0.849 & 0.686 & 0.216 \\
\hline Female & 0.31 & 0.31 & 0.001 & 0.010 & 0.946 \\
\hline Swiss & 0.81 & 0.84 & 0.029 & 0.008 & 0.000 \\
\hline
\end{tabular}

Note: Descriptive statistics and t-tests of the sample comparing the means of property and buyer characteristics between 2011 and 2013. Based on individual-level transaction data in Zurich in 2011 and 2013. Data stem from the Cantonal Statistical Office in Zurich. 
FIG. 7: Robustness CHECK: Foreign RESidents ARE NOT AFFECTED By REFORM

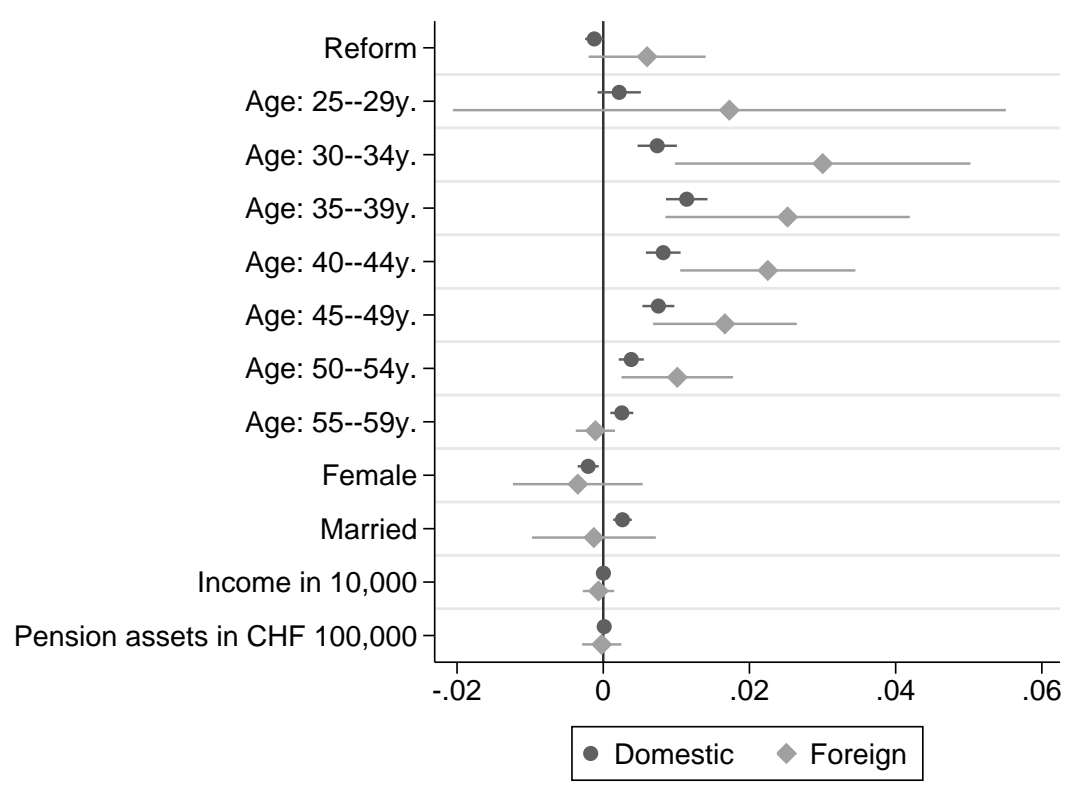

Note: OLS regressions. The dependent variable is the share of pension assets claimed as advance withdrawal. Standard errors are clustered at the individual level. Sample is unbalanced including those who are observed only in either 2011 or 2013. Sample sizes are 67,503 and 4,087 for the domestic and foreign residence samples, respectively. 
FIG. 8: NeWSPAPER COVERAGE ON THE PROMOTION OF HOME OWNERSHIP

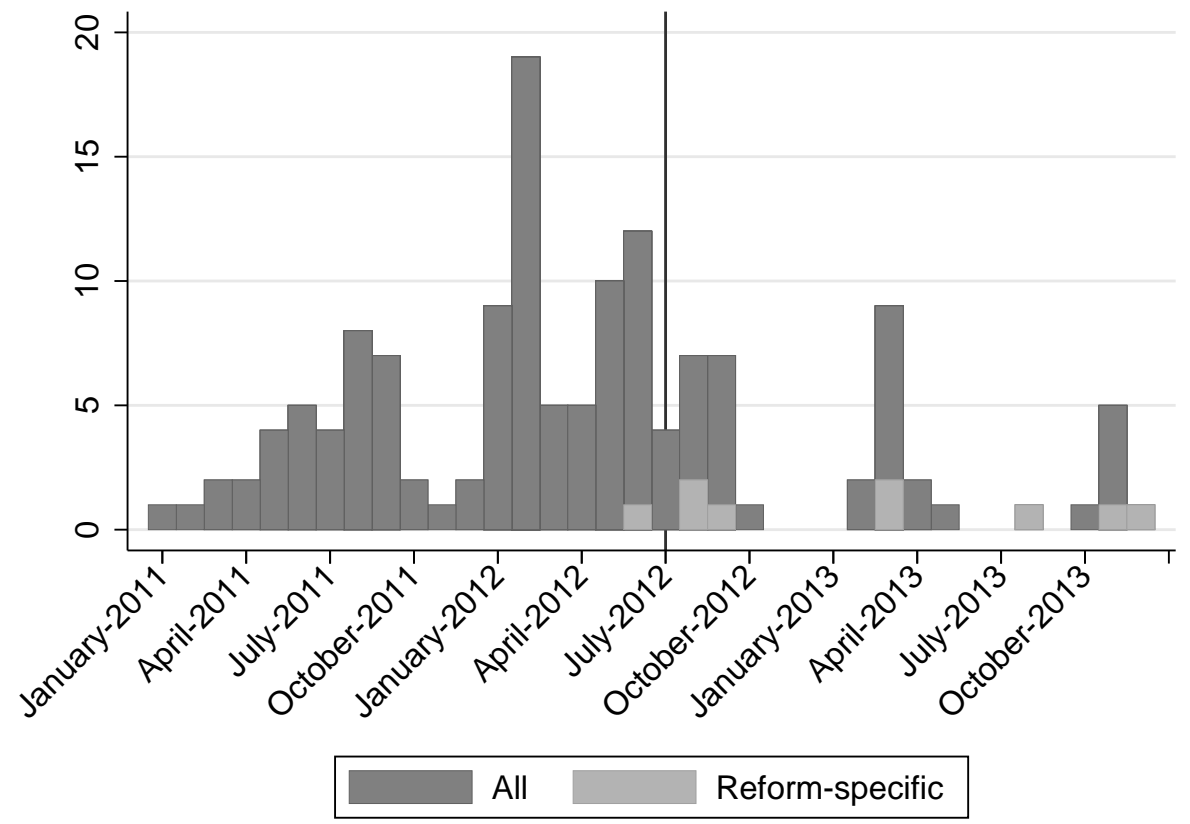

NotE: Monthly numbers of newspaper articles related to the reform in 22 major Swiss newspapers between January 2011 and December 2014. The vertical line depicts the reform date. 
FIG. 9: Pension assets And total NON-PENSion FinanCial Assets

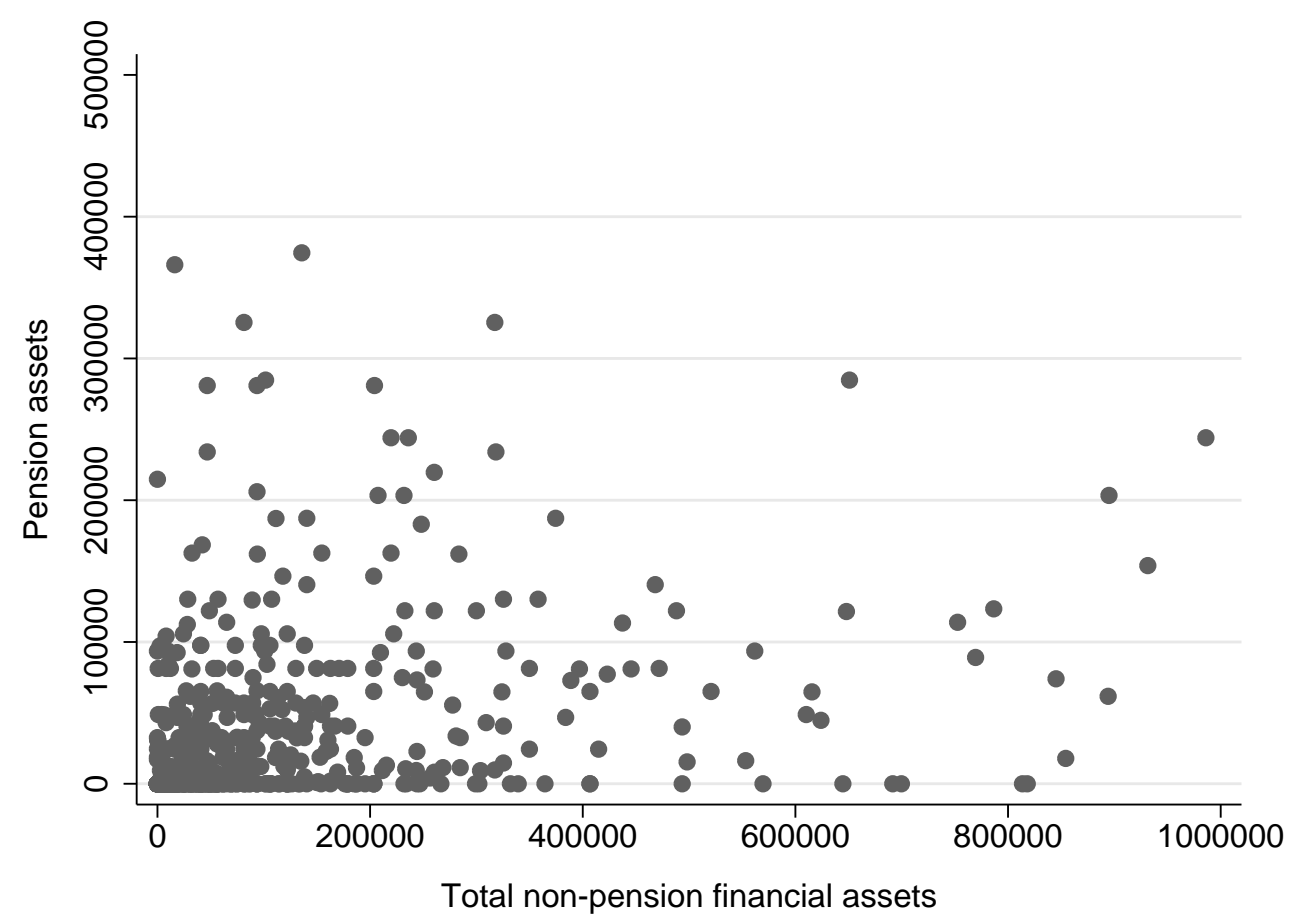

Note: Data stem from the Survey of Health, Ageing and Retirement in Europe. Observations are restricted to Swiss respondents aged 50-64 years with a maximum non-pension wealth of CHF 1,000,000 and maximum pension assets worth CHF 500,000. 
FIG. 10: COMPARISON OF THE NUMBER OF ADVANCE WITHDRAWALS IN OUR DATASET WITH THE ANNUAL REPORT OF THE PENSION PROVIDER

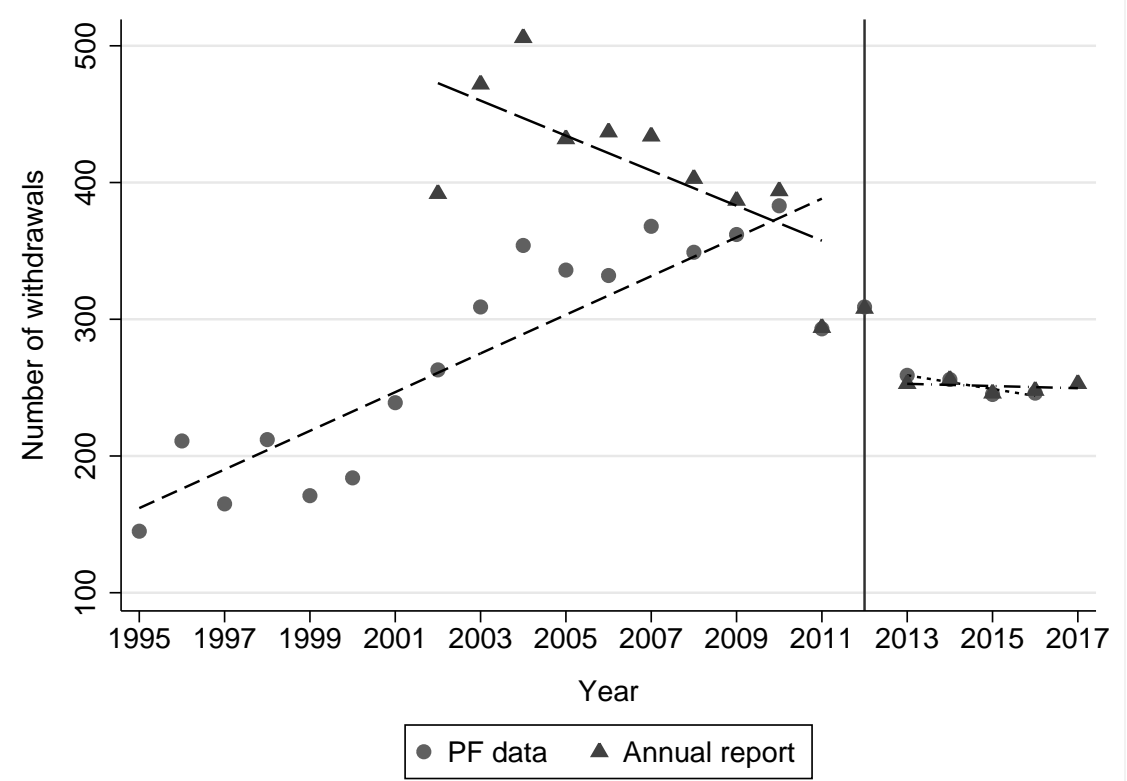

Note: Number of advance withdrawals for home ownership from the second pillar by year of withdrawal. The vertical line depicts the reform date. Data stem from the pension provider. We do not observe around $28.7 \%$ of withdrawals between 2002 and 2006 in our data, but this share of missing observations drops to $9.5 \%$ between 2007 and 2010 . 
FIG. 11: ReAl WAGE PER YeAR in Switzerland

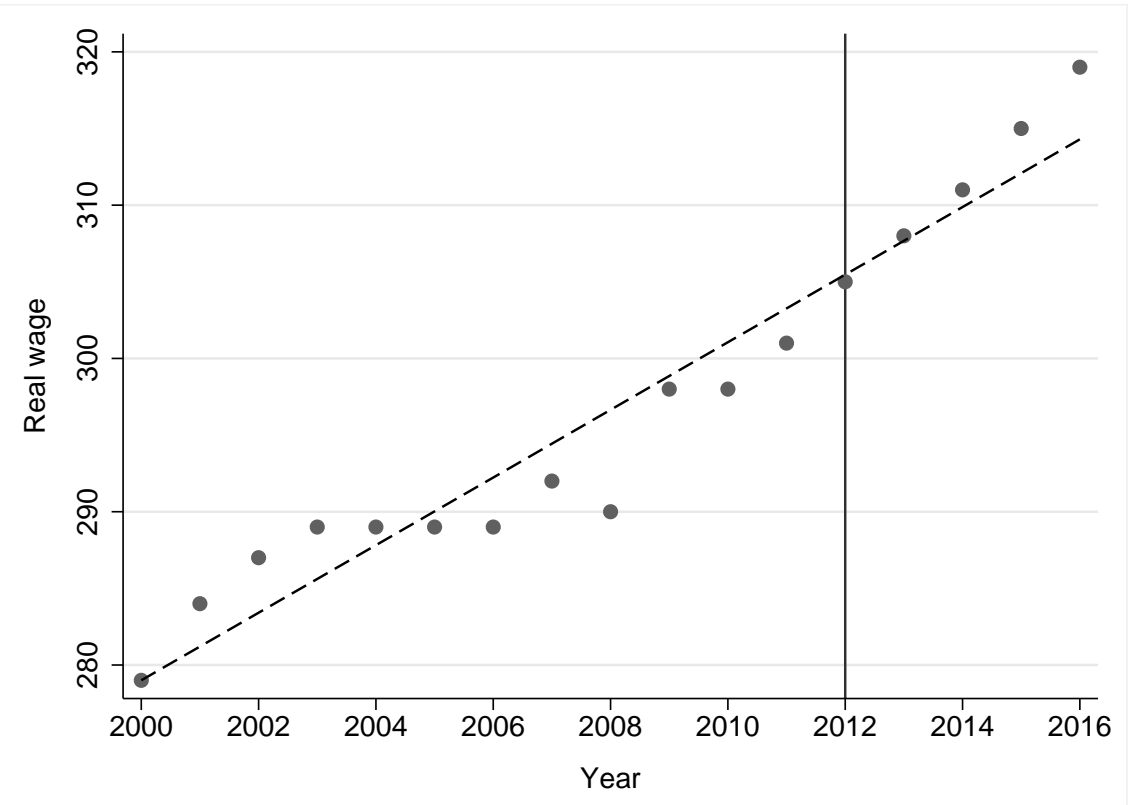

Note: Real wage per year in Switzerland between 2000 and 2016 (basis $1939=100$ ). The vertical line depicts the reform date. Data stem from the Federal Statistical Office.

FIG. 12: UnEMPlOyment RATE PER QUARTER IN SwitZeRland

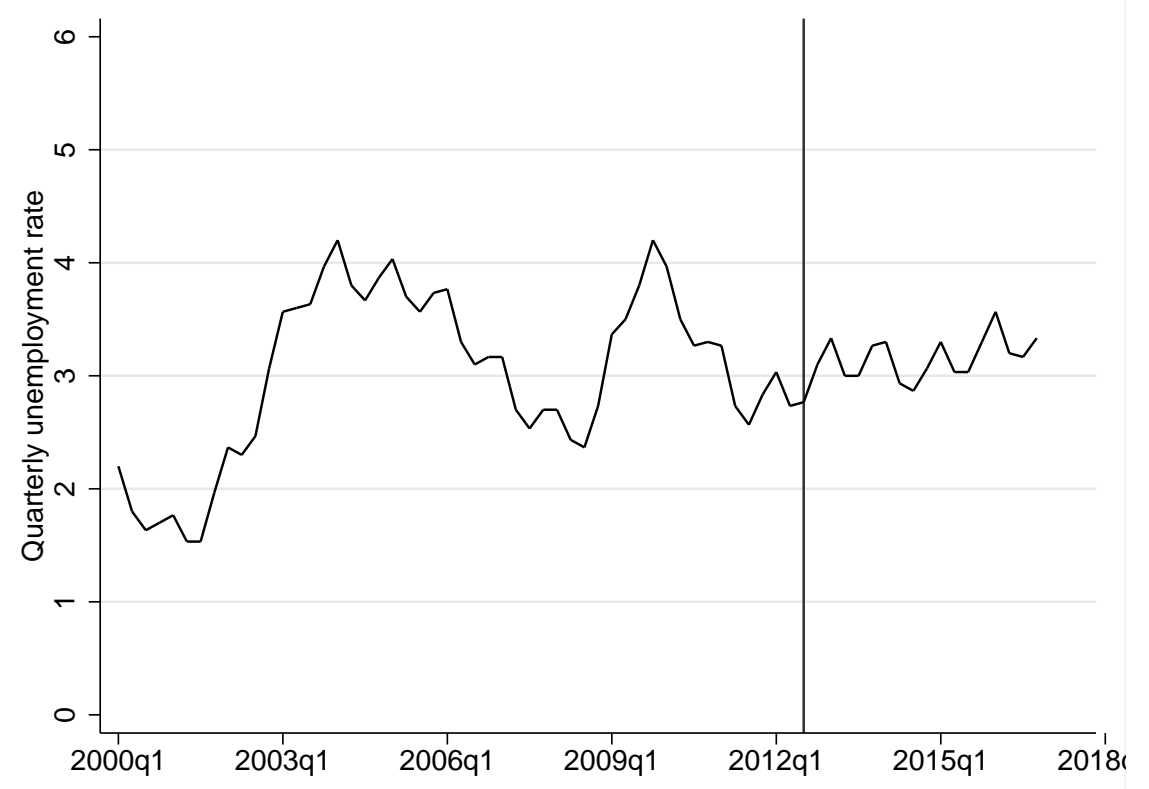

Note: Unemployment rate per quarter in Switzerland between 2000q1 and 2016q4. Monthly data are interpolated to quarterly data. The vertical line depicts the reform date. Data stem from the State Secretariat for Economic Affairs. 
FIG. 13: Monthly INTERest RATES IN Switzerland

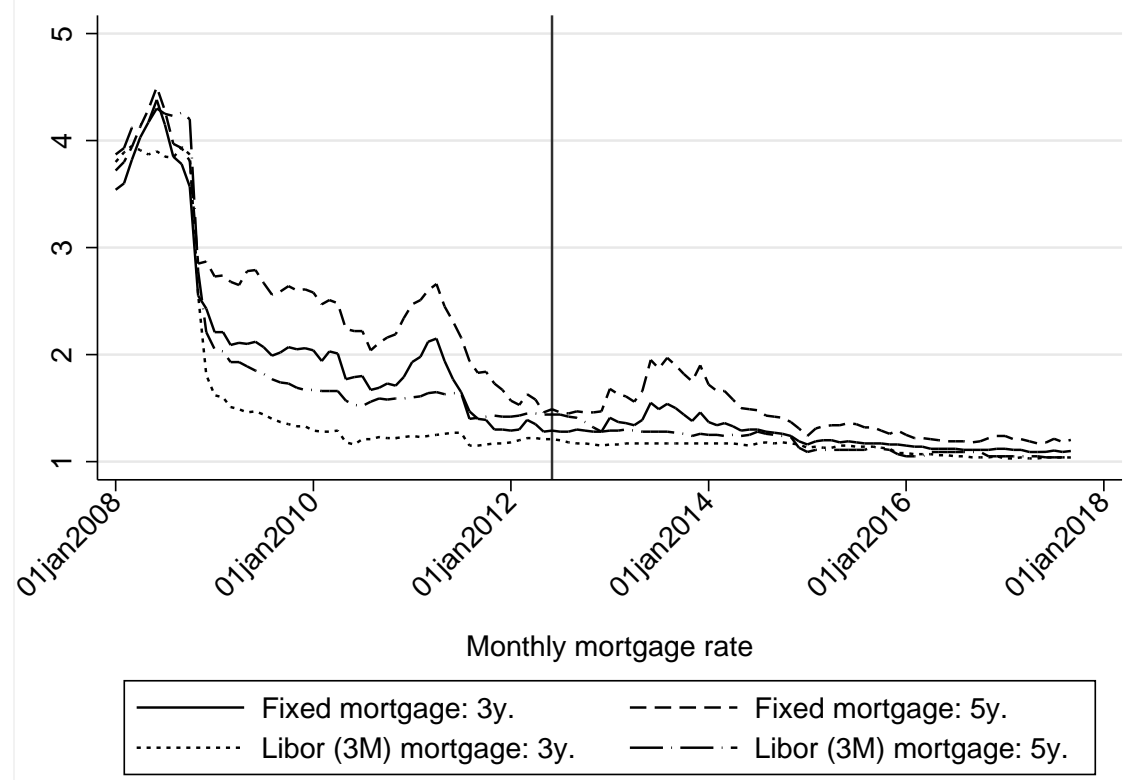

Note: Monthly interest rates in Switzerland between January 2008 and September 2017. The vertical line depicts the reform date. Data stem from the Swiss National Bank.

FIG. 14: Domestic MORTGage Claims PeR Year in Switzerland

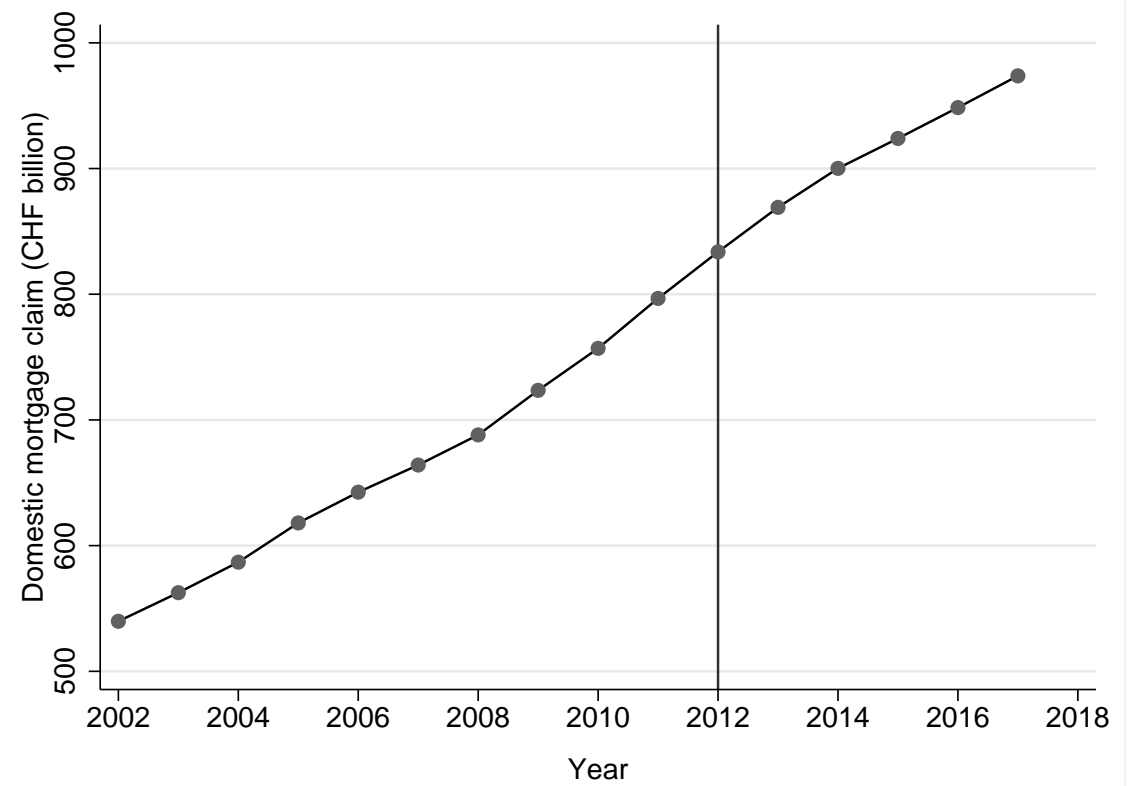

Note: Annual domestic mortgage claims in Switzerland between 2002 and 2017. The vertical line depicts the reform date. Data stem from the Swiss National Bank. 
FIG. 15: REAL ESTATE PRICES PER YEAR IN SWITZERLAND

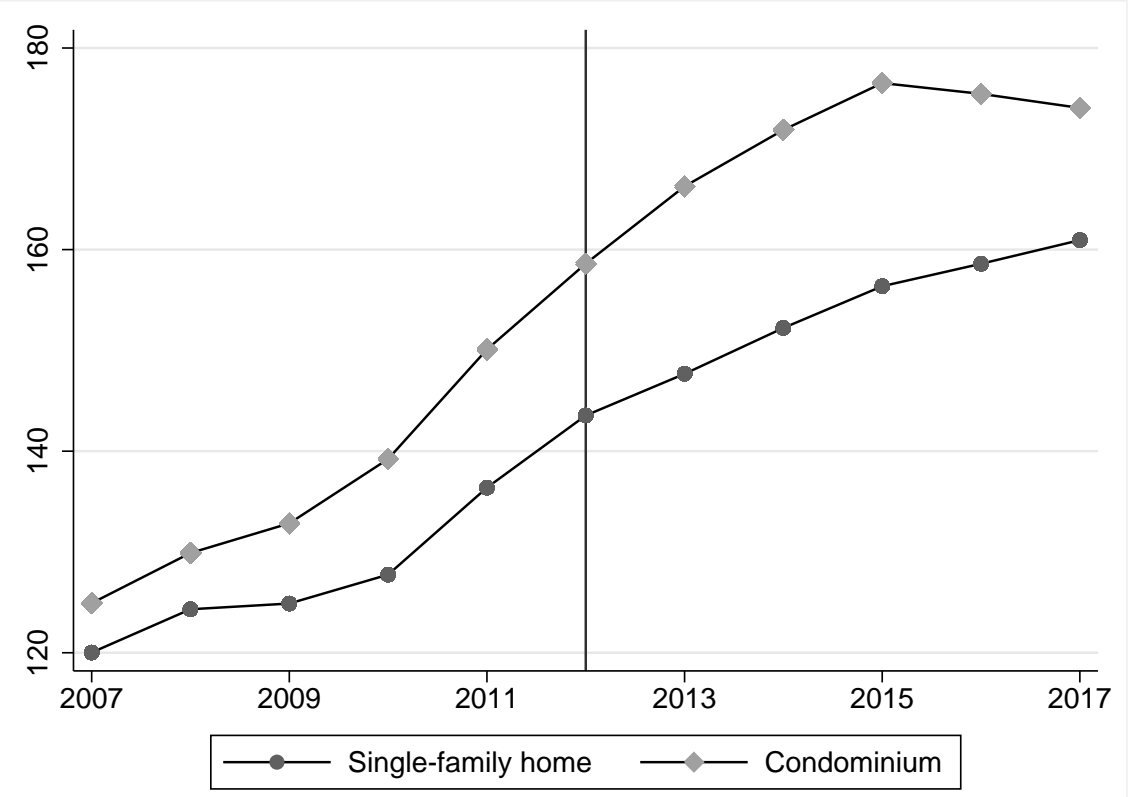

Note: Single-family home and condominium transaction price indices per year in Switzerland between 2007 and 2017. Price indices reflect prices of a medium-sized property with average amenities. The vertical line depicts the reform date. Data stem from Wüst Partner.

FIG. 16: FEMALE SHARE OF ADVANCE WITHDRAWERS PER YEAR

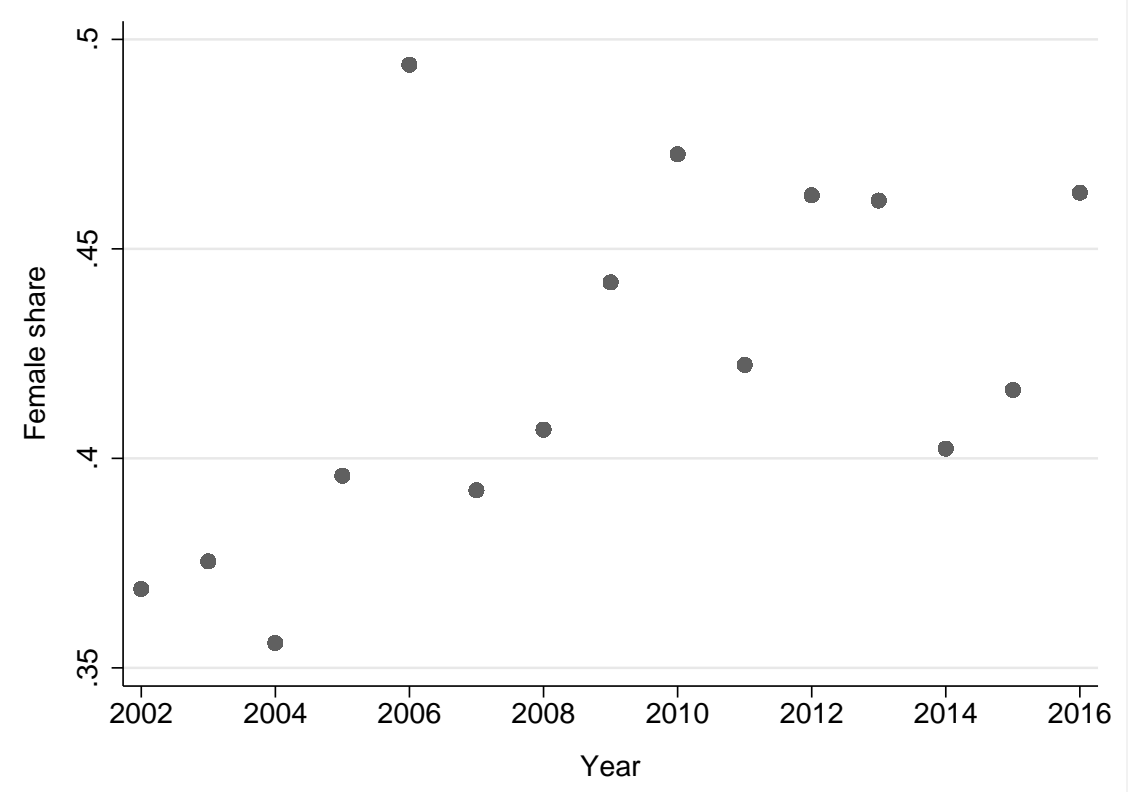

Note: Female share of advance withdrawers per year between 2002 and 2016. Data stem from the pension provider. 
FIG. 17: Average AgE AT Withdrawal PER YeAR

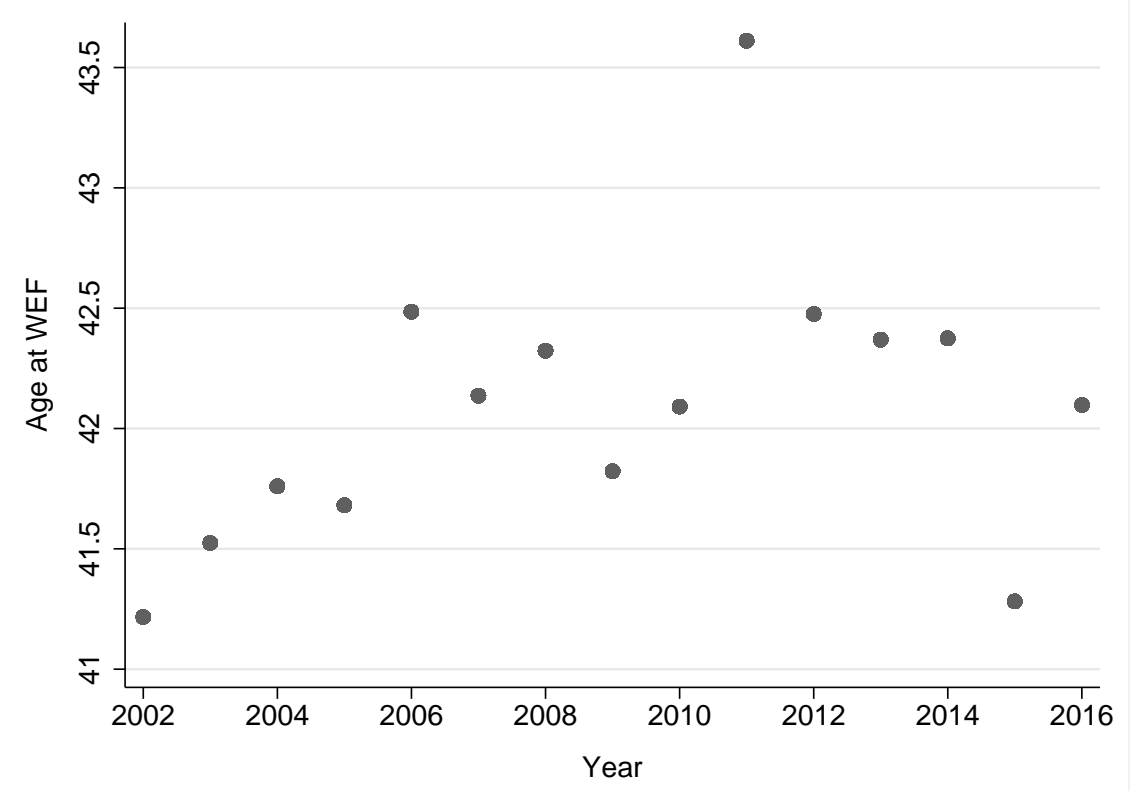

Note: Average age at withdrawal per year between 2002 and 2016. Data stem from the pension provider. 
FIG. 18: SHARE OF ADVANCE WITHDRAWALS PER YEAR BY REGION
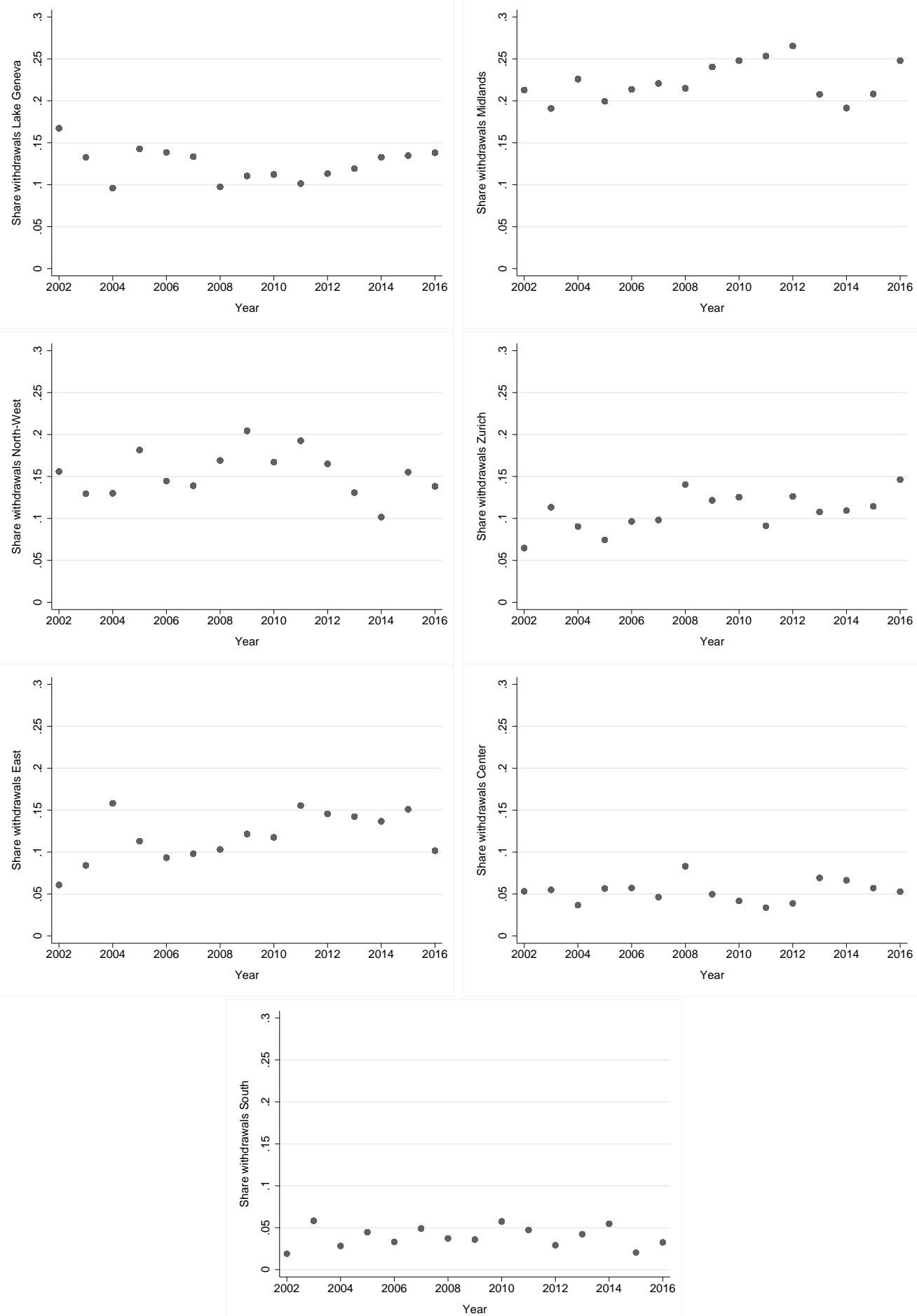

Note: Share of advance withdrawals per year by region between 2002 and 2016. For statistical purposes, Switzerland is subdivided into seven regions at the NUTS-2 level (The Classification of Territorial Units for Statistics). 
FIG. 19: CORRELATION BETWEEN WITHDRAWERS' PENSION ASSETS AND RELATIVE SHARES OF PENSION ASSETS WITHDRAWN BY REFORM

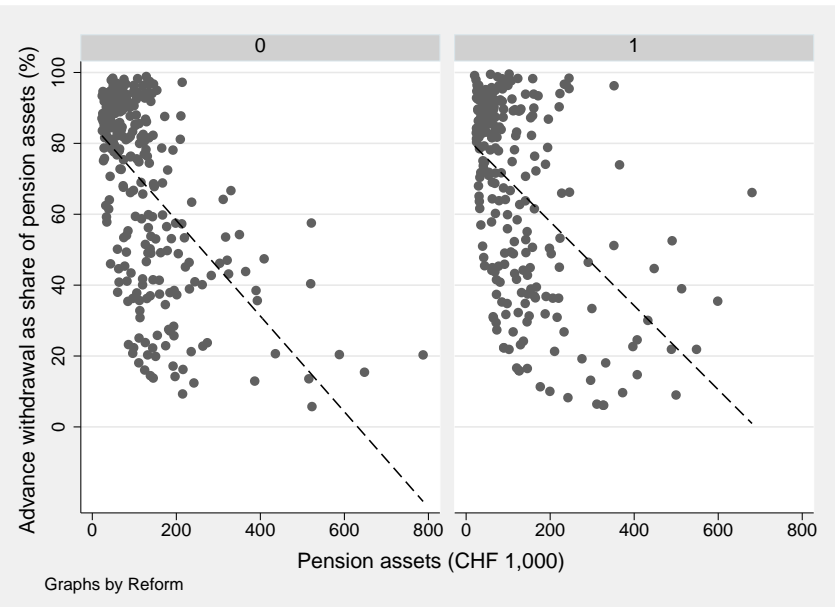

Note: Correlation between withdrawers' pension assets in CHF 1,000 and relative shares of pension assets withdrawn by reform. 
FIG. 20: MARGinal EFFECT OF THE REForm BY AGE

(a) Extensive margin: probability to withdraw pension assets in advance

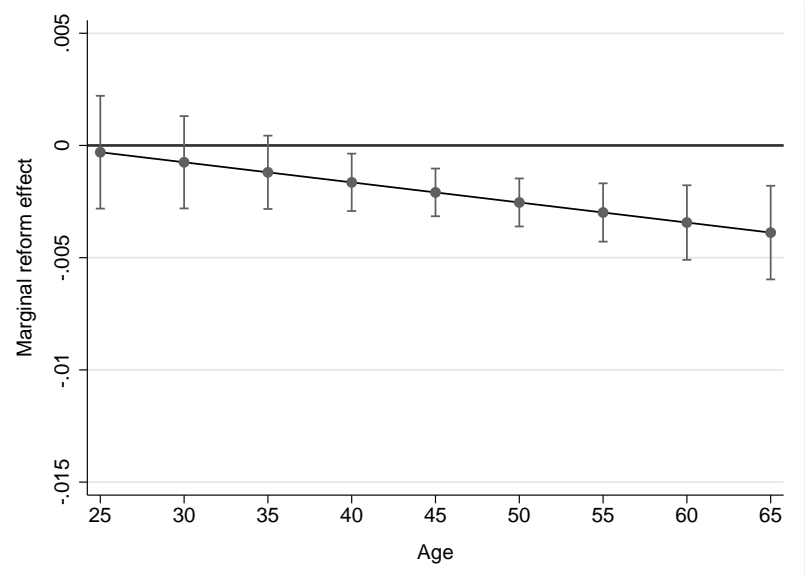

(b) Intensive margin: share of pension assets claimed as advance withdrawal

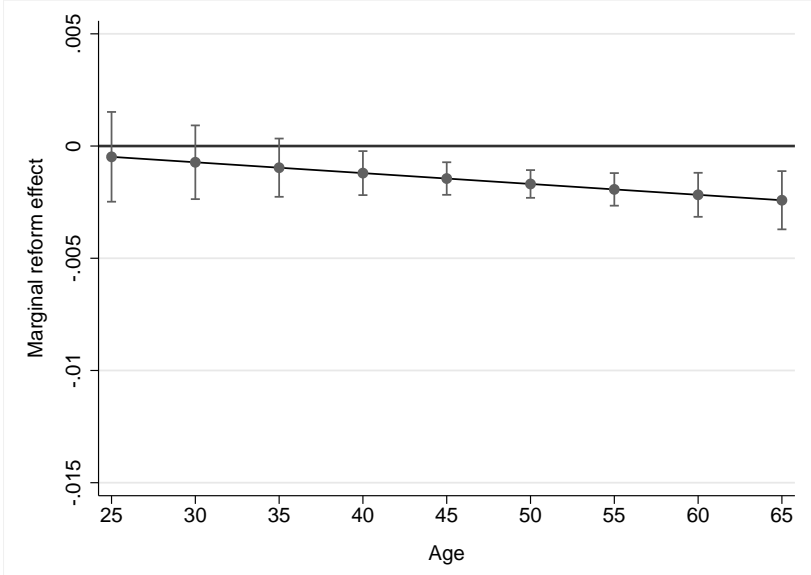


FIG. 21: MARGINAL EFFECT OF THE REFORM BY INCOME: INTENSIVE MARGIN

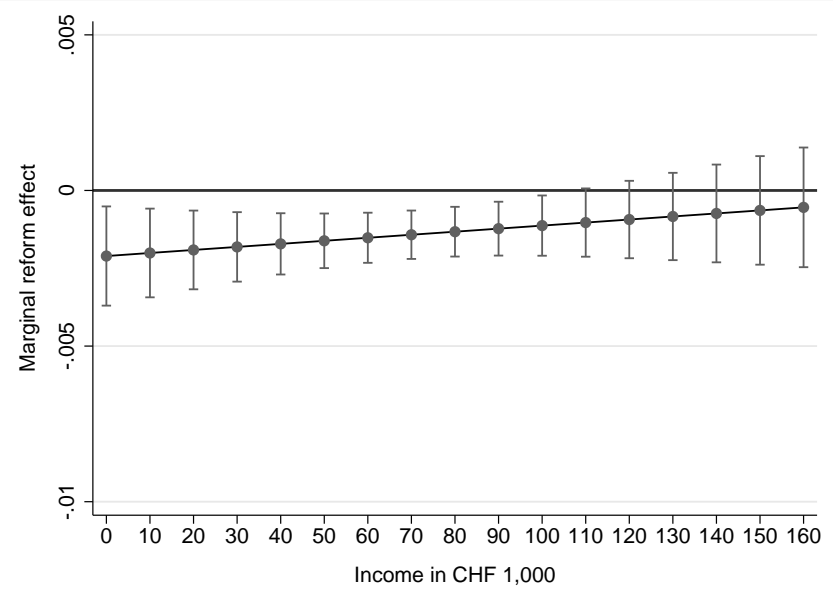

Note: Marginal effect of the reform on the share of pension assets claimed as advance withdrawal by income in CHF 1,000. 
FIG. 22: MARGINAL EFFECT OF THE REFORM BY PENSION ASSETS: INTENSIVE MARGIN

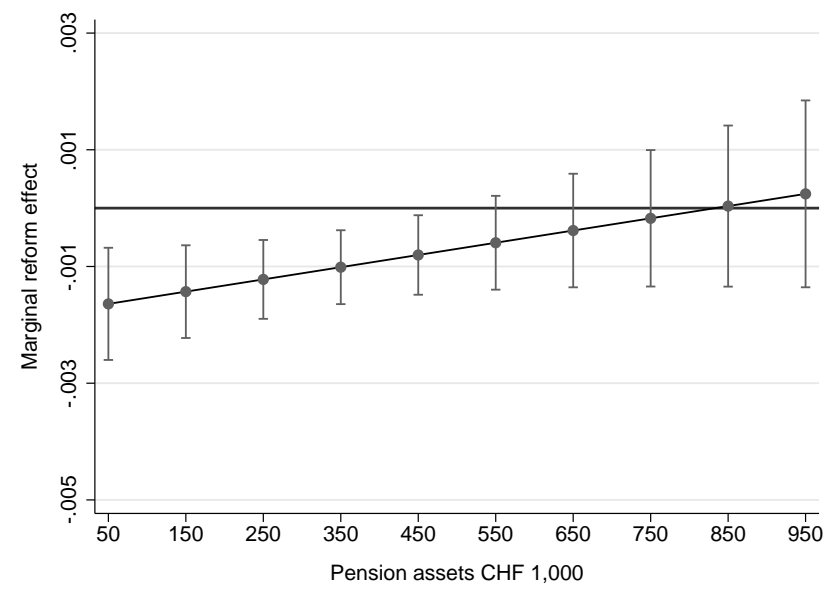

Note: Marginal effect of the reform on the share of pension assets claimed as advance withdrawal by pension assets in CHF 1,000. 


\section{Newspaper search}

We looked for newspaper articles referring to the promotion of home ownership and directly referring to the reform of stricter equity regulations published in 22 major national Swiss newspapers between January 1, 2011 and December 31, 2014. The number of articles before the implementation of the reform should give insight into the possibility of anticipation effects. In Figure 8 the dark bars illustrate the number of monthly articles on the home ownership promotion in general $(A l l)$ and the light bars illustrate the number of monthly reform-specific articles (Reform-specific). The following keywords were used and combined in the newspaper database factiva: All key words were "promotion of home ownership", "advance withdrawal of pension assets", "equity restriction", and "Swiss Bankers Association". Reformspecific key words were "advance withdrawal of pension assets", and "equity restriction". Our search first focused on the four major national newspapers: NZZ, Tages-Anzeiger, Blick, and Sonntagszeitung. We then extended our focus to regional newspapers, such as St. Galler Tagblatt, Zofinger Tagblatt, Aargauer Zeitung, Basler Zeitung, Berner Zeitung, Die Südostschweiz, and Der Bund. 